Article

\title{
Impact of the Middle Eocene Climatic Optimum (MECO) on Foraminiferal and Calcareous Nannofossil Assemblages in the Neo-Tethyan Baskil Section (Eastern Turkey): Paleoenvironmental and Paleoclimatic Reconstructions
}

\author{
Roberta D'Onofrio ${ }^{1, *}$, Amr S. Zaky ${ }^{2,3}{ }^{1}$, Fabrizio Frontalini ${ }^{4}{ }^{(}$, Valeria Luciani ${ }^{1}$, Rita Catanzariti ${ }^{5}$, \\ Fabio Francescangeli ${ }^{6}$, Martino Giorgioni ${ }^{7}$, Rodolfo Coccioni ${ }^{4}$, Ercan Özcan ${ }^{8}$ (D) and Luigi Jovane ${ }^{9}$ (i)
}

check for updates

Citation: D'Onofrio, R.; Zaky, A.S.; Frontalini, F.; Luciani, V.;

Catanzariti, R.; Francescangeli, F.; Giorgioni, M.; Coccioni, R.; Özcan, E.; Jovane, L. Impact of the Middle Eocene Climatic Optimum (MECO) on Foraminiferal and Calcareous Nannofossil Assemblages in the Neo-Tethyan Baskil Section (Eastern Turkey): Paleoenvironmental and Paleoclimatic Reconstructions. Appl. Sci. 2021, 11, 11339. https://doi.org/ 10.3390/app112311339

Academic Editor: Daniel Dias

Received: 20 October 2021

Accepted: 24 November 2021

Published: 30 November 2021

Publisher's Note: MDPI stays neutral with regard to jurisdictional claims in published maps and institutional affiliations.

Copyright: (C) 2021 by the authors Licensee MDPI, Basel, Switzerland. This article is an open access article distributed under the terms and conditions of the Creative Commons Attribution (CC BY) license (https:/ / creativecommons.org/licenses/by/ $4.0 /)$.
Dipartimento di Fisica e Scienze della Terra, University of Ferrara, 44121 Ferrara, Italy; lcv@unife.it

2 Institute of Geological Sciences, Oeschger Centre for Climate Change Research, University of Bern, 3012 Bern, Switzerland; amr.zaky@geo.unibe.ch

3 Geology Department, Faculty of Science, Menoufia University, Shebin El-Kom 32511, Egypt

4 Dipartimento di Scienze Pure e Applicate (DiSPeA), Università degli Studi di Urbino "Carlo Bo", 61029 Urbino, Italy; fabrizio.frontalini@uniurb.it (F.F.); rodolfo.coccioni@uniurb.it (R.C.)

Istituto di Geoscienze e Georisorse CNR, 56124 Pisa, Italy; rita.catanzariti@igg.cnr.it

6 Centre for Earth System Research and Sustainability, Institute for Geology, University of Hamburg, Bundesstraße, 55, 20146 Hamburg, Germany; fabio.francescangeli85@gmail.com

7 Instituto de Geociências da Universidade de Brasília, Campus Universitário Darcy Ribeiro ICC, Ala Central, Brasília 70910-900, Brazil; gmartino@unb.br

8 Department of Geological Engineering, Faculty of Mines, İstanbul Technical University (İTÜ), Maslak, Istanbul 34469, Turkey; ozcanerc@itu.edu.tr

9 Instituto Oceanográfico da Universidade de São Paulo, Praça do Oceanográfico, 191, São Paulo 05508-120, Brazil; jovane@usp.br

* Correspondence: dnfrrt@unife.it

Featured Application: A challenging issue for humankind is the understanding of the future biota state within the context of global change (anthropogenic $\mathrm{CO}_{2}$ emissions, global warming, ocean acidification, eutrophication, anoxia). Studies on modern biomaterials reveal that the climate-induced environmental stress is affecting the stability of ecosystems. However, modern analyses are limited to decades/historical times whereas the paleontological record can reconstruct the impact of past global climate analogues on a thousand/hundreds/million-year perspective. This work fits the goal to deciphering how marine calcareous nannofossils, benthic and planktic foraminifera, unicellular algae and protozoan, reacted to the global warming known as Middle Eocene Climatic Optimum (MECO), centered at $40 \mathrm{Ma}$ ago and lasting 500-600 kyr. Our detailed integrated reconstruction from the Neo-Tethyan geological setting (eastern Turkey) with thousand years' resolution ( $100 \mathrm{~m} / \mathrm{My})$ reveals that the MECO warming peak induced marked water eutrophication, reduction in oxygen availability at the sea floor and carbonate dissolution. Part of the analyzed marine biota proved to be resilient to the MECO perturbation through marked modifications within assemblages whereas the most specialized planktic foraminifera declined permanently their abundance permanently. Biota and environment only partially recovered the pre-event conditions after the MECO warming peak. Our study, recording transient and permanent changes, allows to understand how paleoenvironment and marine biota reacted to the global MECO perturbation.

Abstract: The Middle Eocene Climatic Optimum (MECO; 40 Ma), which interrupted for 500-600 kyr the long-term cooling trend culminating at the Eocene/Oligocene boundary, still requires a comprehensive understanding of the biotic resilience. Here we present a high-resolution integrated foraminiferal and calcareous nannofossil study across the MECO from the expanded and continuous Tethyan Baskil section (eastern Turkey) that offers a complete magneto-biostratigraphic and geochemical framework. The five MECO phases identified reveal a transition from oligotrophic (pre-MECO) to eu-mesotrophic conditions, possibly related to accelerated hydrological cycle, during the initial 
$M E C O$ and MECO $\delta^{13} \mathrm{C}$ negative excursion phases. The MECO WARMING PEAK phase, marking the highest carbonate dissolution interval, records the most striking biotic changes, such as peak in warm and eutrophic nannofossils, virtual disappearance of the oligotrophic planktic foraminiferal large Acarinina and Morozovelloides, and peak in eutrophic deep dwellers Subbotina. Benthic foraminifera suggest in this phase an improvement in the quality of organic matter to the seafloor. The post-MECO phase shows only a partial recovery of the pre-event conditions. Large Acarinina and Morozovelloides did not recover their abundance, possibly due to cooler conditions in this phase. Our reconstruction reveals how paleoenvironment and marine biota from the studied Neo-Tethyan setting reacted to the MECO perturbations.

Keywords: planktic foraminifera; benthic foraminifera; calcareous nannofossils; middle eocene climatic optimum; Neo-Tethys; biota resilience; warming event analogues

\section{Introduction}

The middle Eocene climatic optimum (MECO) is still an enigmatic global warming event, which occurred at about $40 \mathrm{Ma}$ and lasted $~ 500-600 \mathrm{kyrs}$, that temporarily interrupted the long-term cooling trend initiated at the end of the early Eocene climate optimum (EECO, 49 Ma) (e.g., [1-4]). The MECO was first recognized by $~ 1 \%$ negative oxygen isotope excursion in bulk carbonate and benthic foraminiferal tests in Southern Ocean cores [5], and subsequently identified in the Atlantic Ocean, and central western Tethys $[1,6-10]$. Bulk carbonate oxygen isotope records indicate $\sim 4-6{ }^{\circ} \mathrm{C}$ warming (assuming ice-free conditions), with a gradual onset and brief peak temperatures, followed by a rapid return to pre-event conditions [1]. The MECO has been described as a global carbon cycle perturbation [11], but the lack of a carbon isotope excursion (CIE) contemporaneous with warming and the duration of the climate anomaly suggest that the event was more complex than the earlier Paleogene hyperthermals [12]. There is no evidence for a sudden release of isotopically light carbon within the MECO warming phase, as for the hyperthermal events. Marine carbonate $\delta^{13} \mathrm{C}$ records show considerable geographic and bathymetric variability but are commonly characterized by rising rather than declining $\delta^{13} \mathrm{C}$ values during the initial gradual warming $[1,5,9,13]$. A transient $\sim 0.5 \%$ negative CIE ( $\sim 50 \mathrm{kyr})$ during the warming peak occurs at some but not all sites [1,3,7-9]. Dissolution in carbonate during the MECO has been recorded in deep-sea records and linked to a temporary rise of the $\mathrm{CCD} /$ lysocline due to the amplified contribution of $\mathrm{CO}_{2}$ (e.g., [1]). The degree and nature of the global carbon cycle disturbance during peak MECO as reflected in the available $\delta^{13} \mathrm{C}$ records appear complex [12], and regional carbon cycle influences were likely important. To explain the timing and pattern of warming and $\delta^{13} \mathrm{C}$ values, Bohaty et al. [1] hypothesized the enhanced degassing of relatively ${ }^{13} \mathrm{C}$-enriched $\mathrm{CO}_{2}$ from magmatic sources (i.e., volcanism) or metamorphic decarbonation in orogenic belts as the cause of the event. Indeed, an early stage of Ethiopian flood basalt activity might have occurred between 45 and $35 \mathrm{Ma}$ [14], and the "Mid-Tertiary Ignimbrite Flare-Up" in Mexico started around 40-38 Ma [15].

An intriguing feature of the MECO is its abrupt termination. Different mechanisms may have acted to culminate this perturbation. Enhanced silicate weathering may have led to an initial temperature drop when $\mathrm{CO}_{2}$ degassing stopped, and derived cooling could have promoted recovery of the organic carbon burial flux, accelerating the sequestration of the excess of carbon e.g., [16]. In marginal continental basins, eutrophication and deposition of organic-rich sediments are commonly associated with MECO warming and the period directly afterward [8,17]. An increase in organic carbon burial after the MECO might have been efficient negative feedback to lower $\mathrm{CO}_{2}$ levels, deepening the $\mathrm{CCD}[1,8]$ and leading to the abrupt increase in carbonate $\delta^{13} \mathrm{C}$ values above the MECO peak warming interval $[1,6-8,10]$. 
Even though the MECO is attracting high attention by the scientific community, studies on the paleoenvironmental changes and paleobiotic effects across the MECO are still limited. As for planktic foraminifera, this event led to a significant crisis in the abundance of muricate planktic foraminifera (large acarininids and Morozovelloides [18-20]) from the MECO peak and temporary loss of photosymbionts (bleaching) in Acarinina [20], possibly caused by the warming itself. Integrated studies of various microfossil and geochemical proxies in a western Tethys section deposited at middle-bathyal paleodepth $[8,9,18,19,21]$ record higher export productivity during the MECO peak and directly afterward. However, there is clear evidence for substantial geographic differences in oceanic productivity during the event. Increased productivity is suggested by an increase of siliceous components and changes in calcareous nannofossils at a number of sites such as Site 1051 (NW Atlantic), Site 738 (Kerguelen Plateau), Sites 748 (Southern Ocean) and 749 (Indian Ocean sector) [22-26]. In contrast, low productivity is recorded at ODP Site 1172 (southern high latitude), Site 702 (subpolar South Atlantic) and equatorial Pacific sites [11,27-31].

To improve the understanding of the MECO impact on the biotic communities, we here present the high-resolution quantitative changes within planktic and benthic foraminiferal and calcareous nannofossil assemblages from the Baskil section (eastern Turkey, NeoTethys) (Figure 1). The sedimentary record of the section offers a solid magneto- and biostratigraphy besides mineralogic and stable isotope curves (Figure 2) that allow us a reliable framework with thousands of years' resolution ( 100 m/My) of the MECO interval $[3,32,33]$. Indeed, the stratigraphic continuity, and the very high sedimentation rate (i.e., 40.3-90.7 m/Myr, [33]) make this section ideal for high-resolution paleoenvironmental reconstructions. Our results allow us to outline a paleoceanographic scenario of this critical warming interval from a crucial Neo-Tethys setting in a key geographic position between the Tethys and the Indian Oceans. 

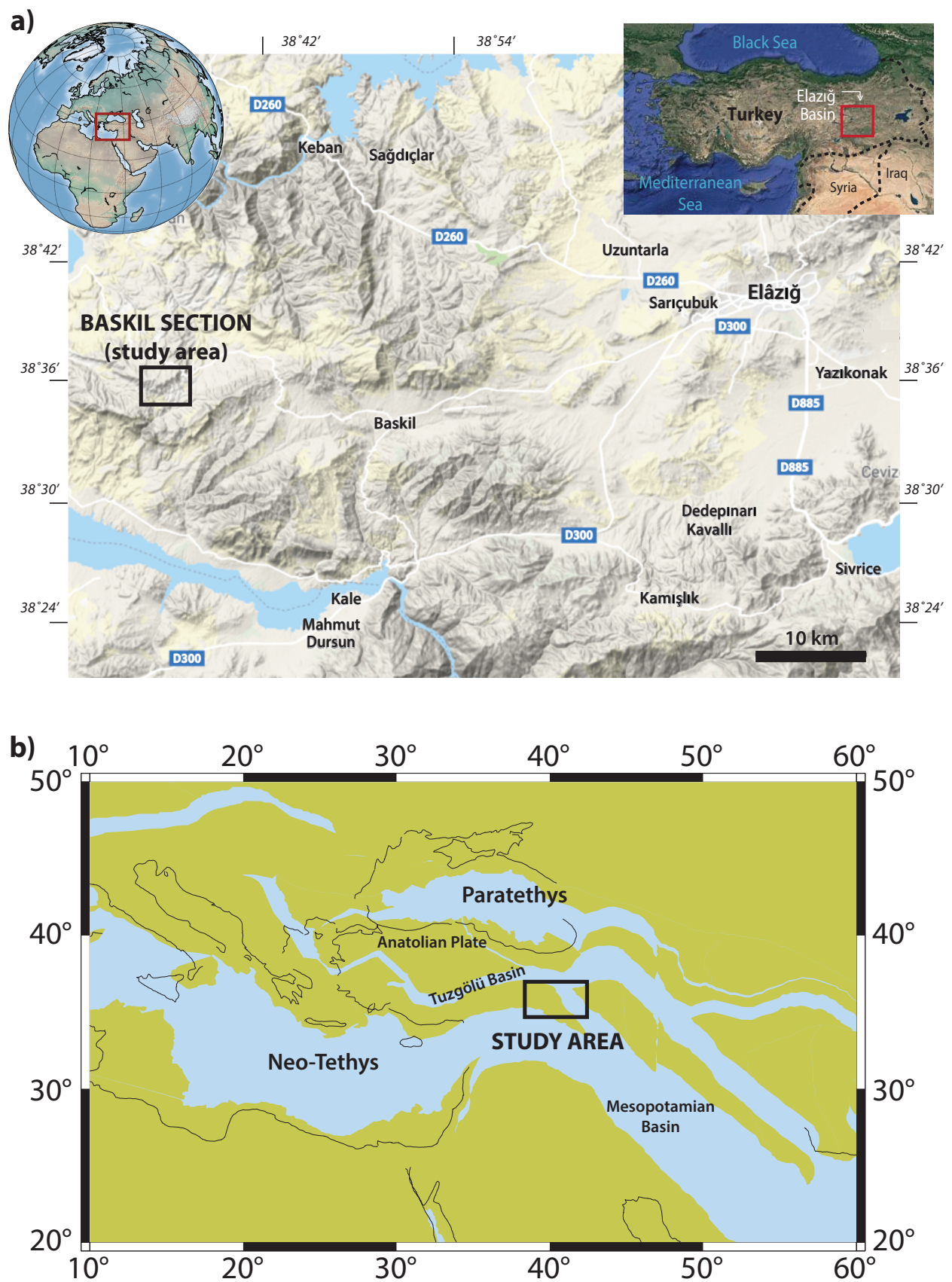

Figure 1. (a) Geographic maps showing the location of the studied area. The base of the terrain map is from Google Maps (Map data@2019 Google; https:/ /www.google.com/maps /@38.6360375,38.927 $7941,10 z$, accessed on 26 November 2021, the satellite map of Turkey at the top right corner is from Google Earth (Map data $@ 2018$ Google; https:/ / www.google.com/maps/); the globe at the top left corner was made using Python 3.4.3-0 with Matplotlib59. (b) Paleogeographic reconstruction of the eastern part of the Neo-Tethys at $\sim 40 \mathrm{Ma}$, showing the paleogeographic location of the studied area (generated with the ODSN Plate Tectonic Reconstruction Service, 2011; http:/ / www.odsn.de/odsn/ services / paleomap/ paleomap.html, accessed on 26 November 2021). Modified from [3]. 


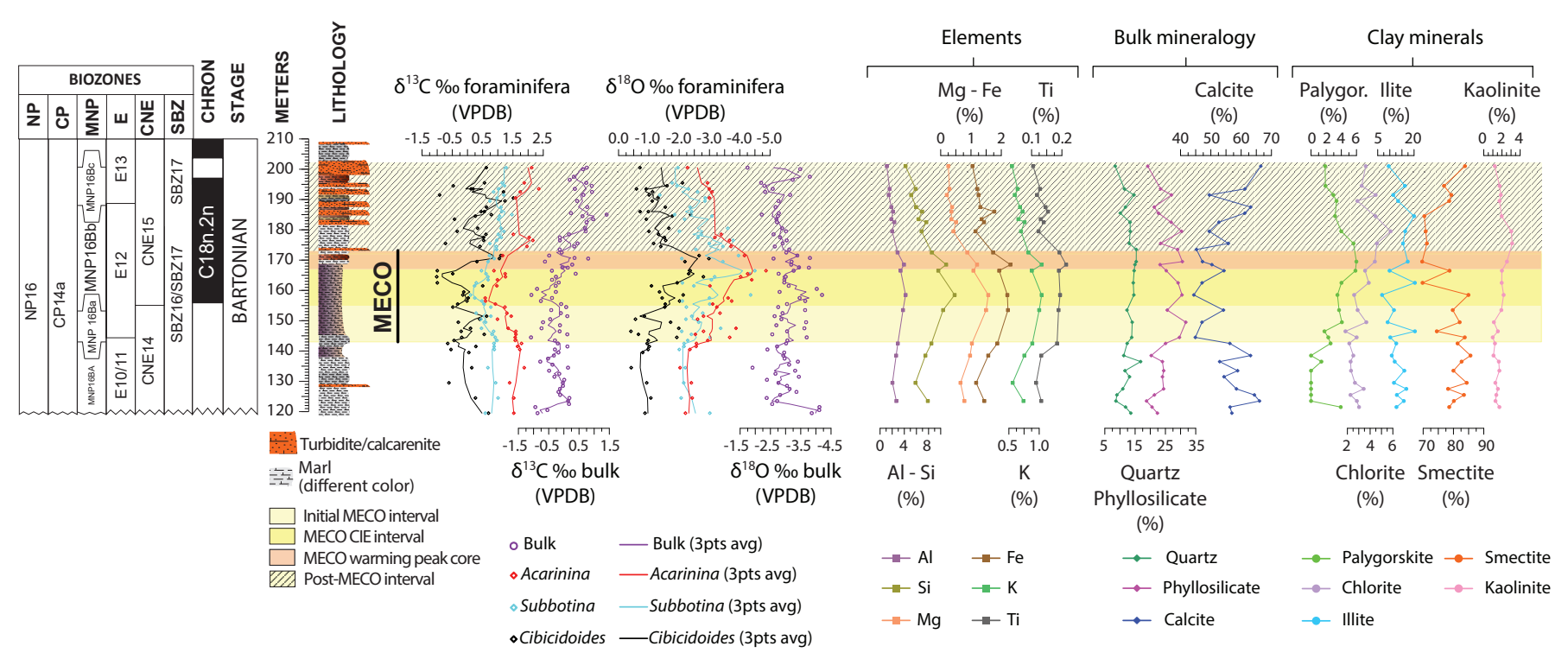

Figure 2. Magnetobiostratigraphy, lithological log, and stable isotopes curves of the Baskil section from [3,33]. Calcareous nannofossil zones and subzones after [34] (listed as NP), [35] (listed as CP), [36] (listed as MNP), and [37] (listed as CNE). Planktic foraminiferal zones are after [38] (listed as E). Larger benthic foraminiferal zones and subzones are after [39,40]. Carbon $\left(\delta^{13} \mathrm{C}\right)$ and oxygen $\left(\delta^{18} \mathrm{O}\right)$ isotopes are shown for three individual genera of foraminifera, representing surface (Acarinina), thermocline (Subbotina) and bottom (Cibicidoides) conditions. Diamonds represent individual data points, whereas solid lines represent curves smoothed by three-point-moving average. The record of elements, bulk mineralogy and clay minerals is from [32]. The colored bands highlight the five identified phases.

\section{Geological Setting, Lithology and Bio-Magnetostratigraphic Framework}

The Baskil section outcrops in eastern Turkey, at ca. $19.8 \mathrm{~km}$ NW of the town of Baskil $\left(38^{\circ} 36^{\prime} 30.34^{\prime \prime} \mathrm{N}, 38^{\circ} 36^{\prime} 03.46^{\prime \prime} \mathrm{E}\right)$ (Figure 1). This section is part of the Kırkgeçit Formation in the Elazığ Basin and was deposited at a paleo-water depth of $\sim 300-600 \mathrm{~m}$ [33]. The total thickness of the section is $385 \mathrm{~m}$ and covers the upper part of the Lutetian up to the lowermost part of the Bartonian [33]. The present study considers the interval from 120 to $200 \mathrm{~m}$ that encompasses the MECO event $[3,33]$. This interval consists of massive hemipelagic marlstone beds, containing calcareous plankton and benthic foraminifera, intercalated with calcarenite beds $15 \mathrm{~cm}$ to $1 \mathrm{~m}$ thick, representing a mixture of siliciclastic grains and bioclasts and including several large benthic foraminifera (LBF) [41,42]. Seven of these turbidites are recorded in the analyzed interval and allowed to define the Shallow Benthic Zones (Figure 2). The hemipelagic sedimentary rocks are interpreted to have been deposited in a back-arc basin on continental crust [43]. Within the Kurkgeçit Formation, the Baskil section has not been deformed and does not show alteration despite the regionally active tectonic regime.

High-resolution integrated magneto- and biostratigraphy provides a detailed age model for the Baskil section due to the continuous, undisturbed, and undeformed sedimentary record [33]. Paleomagnetic analyses resulted in twelve magnetozones that were correlated to the geomagnetic polarity timescale (GPTS) of [44]. The interval here investigated span from middle C19r to the lowermost part of C18n.1n (Figure 2). Giorgioni et al. [3] published oxygen and carbon stable isotopes on benthic (Cibicidoides) and planktic (Acarinina and Subbotina) foraminifera that well constrain the MECO isotopic signatures (Figure 2). In addition, detailed mineralogic data to unravel climate changes have been provided by Rego et al. [32] (Figure 2).

Fossil assemblages $[32,33,42]$ show that the Baskil section cover the top of NP15 to the base of NP18 of calcareous nannofossil zonation of Martini [34]; CP14a to CP15 zonation of Okada and Bukry [35]; MNP16A to MNP18B of Fornaciari et al. [36]; CNE13 to CN18 of Agnini et al. [37]; SBZ16/17-SBZ18A of Less and Ozcan [40]. Planktic foraminifera assem- 
blages indicate that the section spans the (undifferentiated) E10/E11 to E14 biozonations of Wade et al. [38]. These data were used to integrate the age model calculated from the magnetostratigraphy. The Baskil section displays one of the best-preserved records of the MECO event [3]. It yielded $\delta^{18} \mathrm{O}$ and $\delta^{13} \mathrm{C}$ values from different foraminiferal genera representing the bottom, thermocline, and surface environments, which show that the MECO perturbation was recorded at all depths (Figure 2). The isotope curves correlate well with those recorded in other oceanic basins, despite the generally lower values that may be attributed to the local conditions of the Baskil setting [3]. The most peculiar feature is a prominent negative CIE occurring at the onset of the MECO, which cannot be clearly correlated with other records and was attributed to a phase of high carbon cycle instability [3].

\section{Materials and Methods}

\subsection{Field Sampling}

A total of sixty-three bulk rock samples were collected at $\sim 120 \mathrm{~cm}$ stratigraphic resolution from the 125-201 m interval at Baskil section, corresponding to a temporal spacing of $\sim 13.5 \mathrm{kyr}$ between samples. Planktic and benthic foraminifera were successfully extracted from the indurate marly limestones and limestones using the cold-acetolyse technique [45]. This technique enabled the extraction of generally easily identifiable foraminifera. The obtained residues were then analyzed with a binocular stereomicroscope to pick planktic and benthic foraminifera.

\subsection{Benthic Foraminifera and Dissolution Proxies}

The quantitative analysis of benthic foraminifera was performed on 63 samples. A representative split of the $125 \mu \mathrm{m}$ fraction was used to pick benthic foraminiferal specimens. At least 300 specimens, where possible, were picked. Benthic foraminiferal taxa were mainly identified following the generic classification of Loeblich and Tappan [46], and other widely adopted Atlas and papers for classification at the specific level [9,47-53]. The planktonic to benthic $(\mathrm{P} / \mathrm{B})$ ratio calculated as $\mathrm{P} /(\mathrm{P}+\mathrm{B}) \times 100$ expressed as percentages of planktonic foraminifera in the total foraminiferal assemblage and the agglutinatedcalcareous $(\mathrm{C} / \mathrm{A})$ ratio expressed as $\mathrm{C} /(\mathrm{A}+\mathrm{C}) \times 100$ were also calculated. Additionally, the percentages of bi-triserial morphogroups and the epifaunal to infaunal (E/I) ratio calculated as E/(E $+\mathrm{I}) \times 100$ were also calculated. Taxa were allocated to infaunal and epifaunal morphogroups, largely following [54-59]. Several benthic foraminiferal assemblage's parameters, namely species richness (S), Fisher $\alpha$ index, Shannon index $\left(\mathrm{H}^{\prime}\right)$, dominance (D), evenness (J), and equitability (E) were calculated using the PAST-Palaeontological Statistics data analysis package (Hammer et al., 2001). Following [60], the fragmentation index (FI) was calculated to estimate carbonate dissolution effects.

\subsection{Planktic Foraminifera}

Planktic foraminifera were studied on 53 samples. A sampling interval of $\sim 2-3 \mathrm{~m}$ was adopted below and above the MECO interval whereas a spacing of $1 \mathrm{~m}$ was used across the MECO.

The relative abundance of genera was counted on a population of $\sim 300$ specimens in the $\geq 63 \mu \mathrm{m}$ size fraction on representative splits of washed residues and expressed in percentage. Foraminiferal taxonomy adopted in this study follows Pearson et al. [61]. We distinguished the forms belonging to genus Acarinina with well-developed muricae and test size $>125 \mu \mathrm{m}$ as 'large acarininids', from the "small acarininids" (medium size $<125 \mu \mathrm{m}$ ). This separation derives from the diverse record exhibited by these two groups in the Tethyan section of northern Italy $[18,19]$. We separated the species Subbotina senni from the other subbotinids because this taxon occupied a different habitat with respect to the other subbotinids that are known as thermocline dwellers. Specifically, this species is considered a mixed-layer form that sank to middle mixed-layer or deeper depths during 
gametogenesis differently form the other species belonging to the genus Subbotina $[61,62]$ and references therein.

\subsection{Calcareous Nannofossils}

Forty samples were prepared as smear slides from unprocessed material following standard procedures [63] and examined using a light microscope at $1250 \times$ magnification. Relative abundances of species were determined adopting quantitative and semiquantitative counting methods. Species were counted on 300 specimens of nannofossils in a variable number of visual fields; index species of Sphenolithus were counted in a prefixed number of taxonomical related forms (usually 100). Specimens of less frequent taxa were counted on a fixed area of each slide, corresponding to $6 \mathrm{~mm}^{2}$.

\subsection{Statistical Analyses}

Taxa belonging to benthic foraminifera, planktic foraminifera and calcareous nannofossils were independently analysed by using a constrained hierarchical clustering analysis (HCA), after a square root transformation of relative species abundances. A similarity tree was produced using the Euclidian distance. Coniss [64] was used as the clustering method. A detrended correspondence analysis (DCA), an ordination method that arranges samples and species along gradients, was carried out on the taxa relative abundances. It arranges samples that are more similar in taxa composition closer together. DCA uses the variation in taxa composition between the samples to determine the underlying gradients influencing the data. The basic assumption of this method is that the most important environmental gradient causes the largest variation in the taxa composition $[65,66]$. By means of a two-way weighted averaging algorithm, the direction of this variation was calculated and represented as the first DCA axis $[67,68]$. We used two packages from the $\mathrm{R}$ software [69]: Rioja was adopted for construction of diagrams with timescale [70] and Vegan [71] was used for the HCA and DCA.

\section{Results}

\subsection{Benthic Foraminifera and Dissolution Proxies}

All samples except T161 (barren) contained benthic foraminiferal specimens. Additionally, samples T137, T168.1, T169, and T197 showed a limited number of specimens and were therefore discarded from statistical analyses. Benthic foraminiferal assemblages are commonly highly diversified and well preserved throughout the studied interval, though the preservation state in the $160-180 \mathrm{~m}$ interval is lower.

The FI (17.5, on average) ranged from 9 to $31 \%$ with the relatively higher values in the interval spanning 167 to $174 \mathrm{~m}$ (Figure 3). The $\mathrm{P} / \mathrm{B}$ ratio $(81 \%$, on average) varied from 25 to $94.5 \%$. Relatively lower P/B values were found in the interval between 168 and $173 \mathrm{~m}$ (Figure 3, Table S1). Specie richness (55.8, on average) varied from 30 to 83 with relatively lower values in the 163-174 m interval (Figure 3, Table S1). Similarly, $\mathrm{H}^{\prime}$ (3.46, on average) and the Fischer $\alpha$ index (64.4, on average) approximately exhibited lower values in the same interval (Figure 3, Table S1).

A total of 200 benthic foraminiferal species belonging to 94 genera were recognized. The most abundant genera (Table 1) were Anomalinoides, Bathysiphon, Bulimina, Cibicidoides, Gyroidinoides, Lagena, Lenticulina, Nodosaria, Nuttallides, Oridorsalis, Osangularia, and Uvigerina. The most abundant species and their mean and maximum percentages are reported in Table 1.

Calcareous taxa representing, on average, $76.9 \%$ of the benthic foraminiferal assemblages largely dominated the assemblages. The C/A ratio ranged from 50.4 to $90.9 \%$ with lower values in correspondence of the interval spanning 168 to $172 \mathrm{~m}$ (Figure 3, Table S1). The assemblages were dominated infaunal taxa. The E/I ratio averaging $31.4 \%$ varied from 13.6 to $65.5 \%$ (Figure 3, Table S1). The highest values of E/I were found in the 168-172 m interval (Figure 3, Table S1). 


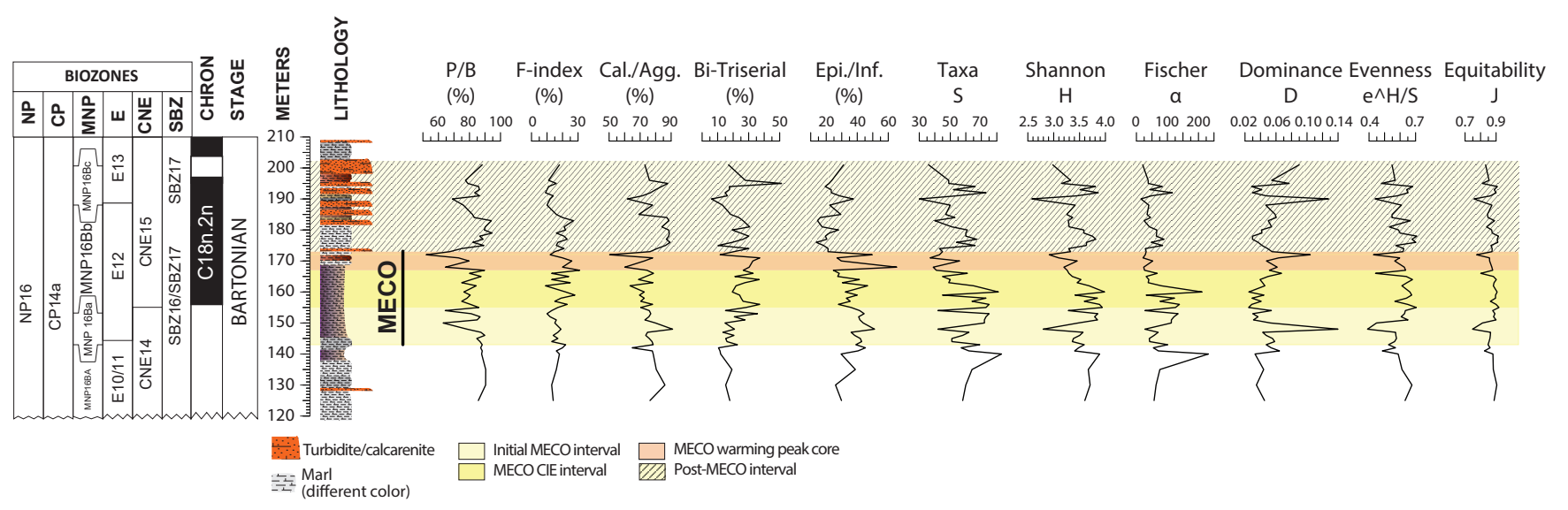

Figure 3. Indices of carbonate dissolution and benthic foraminiferal assemblage's parameters from the Baskil section. $\mathrm{P} / \mathrm{B}$ : planktic to benthic $(\mathrm{P} / \mathrm{B})$ ratio calculated as $\mathrm{P} /(\mathrm{P}+\mathrm{B}) \times 100$ expressed as percentages of planktonic foraminifera in the total foraminiferal assemblage; FI: Fragmentation index calculated according to [60]; $\mathrm{C} / \mathrm{A}$ : calcareous-agglutinated ratio expressed as $\mathrm{C} /(\mathrm{A}+\mathrm{C}) \times 100 ; \mathrm{B} /$ triserial: percentages of bi-triserial morphogroups; $\mathrm{E} / \mathrm{I}$ : epifaunal to infaunal (E/I) ratio calculated as E/ $(E+I) \times 100$; S: species richness; Fisher $\alpha$ index, $\mathrm{H}^{\prime}$ : Shannon index; D: dominance; J: evenness, E: equitability (calculated using the PAST-Palaeontological Statistics data analysis package, [72]). Magneto-biostratigraphy and lithostratigraphy as in Figure 2.

Table 1. Most abundant benthic foraminiferal genera and species from the Baskil section.

\begin{tabular}{cccc}
\hline Most Abundant Genera & Most Abundant Species & Average (\%) & Maximum (\%) \\
\hline Anomalinoides & Anomalinoides alazanensis & 1.5 & 16.5 \\
& Anomalinoides spissiformis & 2.0 & 6.9 \\
Bathysiphon & Asterigerina fimbriata & 2.6 & 25.4 \\
Bulimina & Bathysiphon sp. & 3.7 & 34.3 \\
Cibicidoides & Cibicidoides hadjibulakensis & 5.0 & 17.2 \\
& Eponides plummerae & 3.2 & 13.2 \\
& Gaudryina sp. & 2.8 & 10.7 \\
Gyroidinoides & Glomospira charoides & 1.8 & 10 \\
& Gyroidinoides complanatus & 1.8 & 3.8 \\
Lagena & Hanzawaia ammophila & 2.7 & 12.4 \\
& Lagena sp. & 1.5 & 7.7 \\
Lenticulina & Laevidentalina gracilis & 1.9 & 6.6 \\
Nodosaria & Lenticulina cultrate & 2.8 & 10.7 \\
Nuttallides & Lenticulina turbinata & 1.6 & 6.0 \\
Oridorsalis & Nodosaria longiscata & 2.1 & 17.3 \\
Osangularia & Nuttallides truempyi & 5.0 & 17.1 \\
Uvigerina & Oridorsalis umbonatus & 3.5 & 15.8 \\
& Osangularia plummearae & 2.1 & 22.7 \\
\hline
\end{tabular}

The 155-172 m interval revealed the highest percentages of bi-triserial forms (Figure 4). The relative abundance of Bulimina cumulative showed some fluctuations with the lowest values in the 171.2-178 $\mathrm{m}$ and 185-191 $\mathrm{m}$ intervals (Figure 4, Table S1). Bulimina alazanensis sporadically occurred in some samples, mostly within 166-168 m interval (Figure 4, Table S1). The 164-171 $\mathrm{m}$ and 181-185.5 m intervals were characterized by higher relative abundance of Uvigerina cumulative (Figure 4, Table S1). The relative abundance of Cibicidoides exhibited a clear increase trend from the base of the studied interval up to $175 \mathrm{~m}$, then showed relatively low values from 175 to $195 \mathrm{~m}$ (Figure 4, Table S1). The interval from 167 to $174 \mathrm{~m}$ was characterized by peaks in abundance of Globobulimina (Figure 4, Table S1). Oridorsalis umbonatus was substantially absent in the lower part of the studied interval but increased in its abundance from $166 \mathrm{~m}$ and, particularly in the 173-181 m interval (Figure 4, Table S1). The cumulative abundance of Nuttalides exhibited 
a significant decrease from the lowermost part of the studied interval up to $162 \mathrm{~m}$; then it showed a marked increase from 171 to $181 \mathrm{~m}$ (Figure 4, Table S1). The relative abundance of Lenticulina cumulative displayed a marked increase from 165 to $171 \mathrm{~m}$ and from 186.5 to $188 \mathrm{~m}$ intervals (Figure 4, Table S1). Glomospira charoides only occurred in the lowermost part of the studied interval up to $163 \mathrm{~m}$; two major peaks of its abundance were found within 144-150 m and 157-159 m intervals (Figure 4, Table S1).

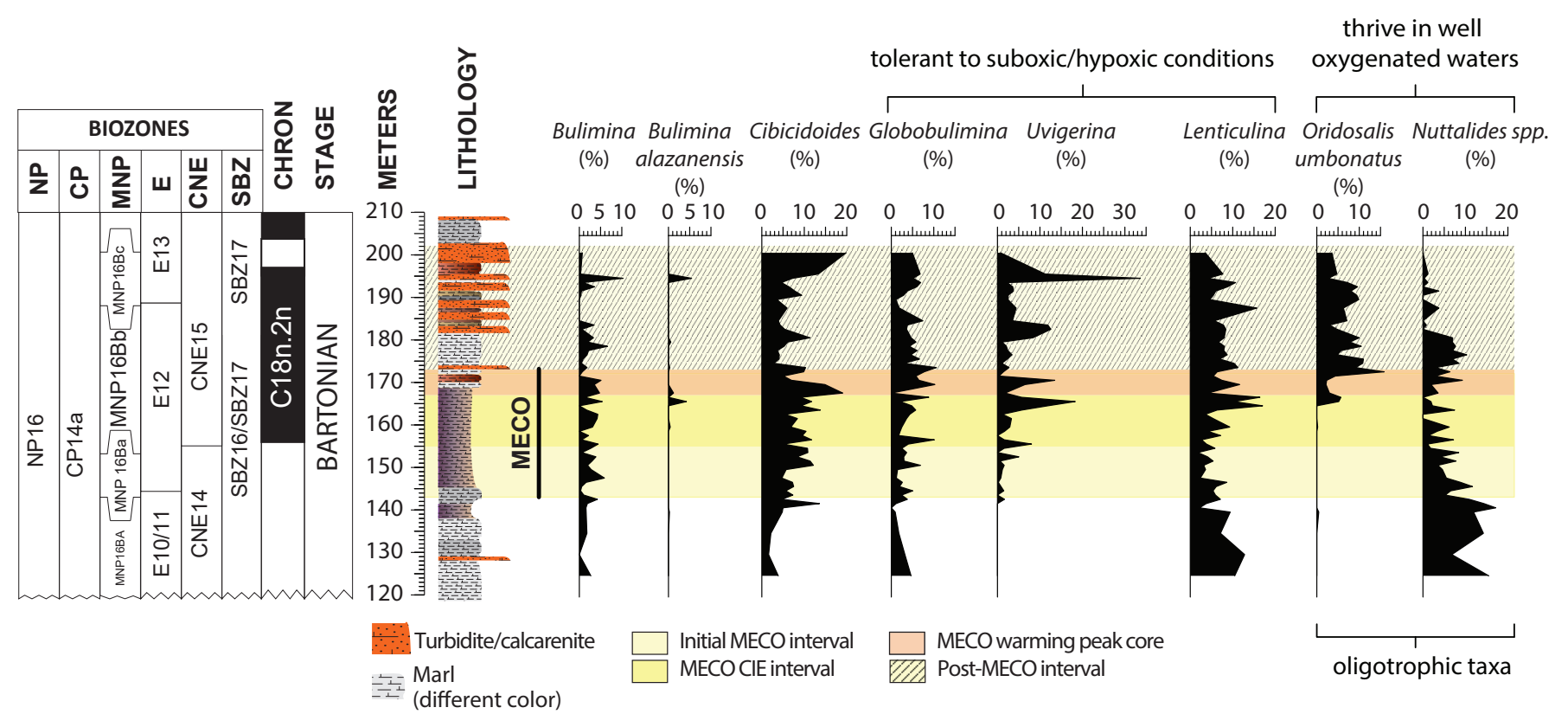

Figure 4. Benthic foraminiferal relative abundance of selected genera and species. The main ecological preferences are also indicated (see text for explanations). Magneto-biostratigraphy and lithostratigraphy as in Figure 2.

\subsection{Planktic Foraminifera}

Planktic foraminiferal assemblages are generally well diversified and recognizable, with the exception of a few samples that show evidence of dissolution (i.e., high tests fragmentation) corresponding to the negative $\delta^{13} \mathrm{C}$ and $\delta^{18} \mathrm{O}$ peak (Figure 2).

The most abundant genus was Subbotina that recorded a mean abundance of $\sim 47.2 \%$ (Figure 5, Table S2). This genus displayed slight increase from a mean abundance of $\sim 39.2 \%$ to $\sim 55.5 \%$ from sample T162 up to top section. The large Acarinina showed a mean abundance of $\sim 25.7 \%$ in the lower part of the section up to the earlier part of the MECO interval then it permanently decreased to less than $\sim 4 \%$ (Figure 5). The genus Morozovelloides displayed a similar trend. In fact, it decreased from mean value in abundance of $\sim 8.1 \%$ to $\sim 1.2 \%$ from sample T170 (Figure 5, Table S2). The genus Globigerinatheka was relatively abundant throughout (mean value $\sim 18 \%$ ). Its percentages showed fluctuations with an increase in abundance from the MECO interval (Figure 5, Table S2). The genera Parasubbotina, Catapsydrax, Globorotaloides and the species Subbotina senni were less abundant throughout the investigated interval as they recorded percentages rarely exceeding $10 \%$. Specifically, Catapsydrax, and Globorotaloides exhibited a slight decrease within the MECO moving from mean values in abundance of $\sim 6 \%$ to $\sim 4.5 \%$ and from $\sim 1.5 \%$ to $\sim 0.4 \%$, respectively (Figure 5, Table S2). These genera increased after the MECO up to $\sim 5.6 \%$ and $\sim 3.6 \%$. An increase in abundance after the MECO was also recorded by S. senni that shifted from mean value of $\sim 1.2 \%$ to $\sim 4.4 \%$ (Figure 5 , Table S2). The genus Hantkenina displayed mean percentages of $\sim 1 \%$ from the base up to sample T165 and became substantially absent in the upper part of the examined section. A decreasing trend in abundance was recorded also from Turborotalia (e.g., T. 'cerroazulensis' group) that moved from a mean value of $\sim 4.6 \%$ to $\sim 1.5 \%$ from sample T165, although it showed peaks in abundance in the MECO interval. 
Finally, the small Acarinina, Planorotalites, Pseudohastigerina, Chiloguembelina and the species Turborotalita carcoselleensis were rare to very rare and/or only sporadically occurring (Figure 5, Table S2). The zonal marker Orbulinoides beckmanni is also very rare as it proved to be included within the statistical population only in a few samples with very low percentages $(0.3-0.5 \%)$.

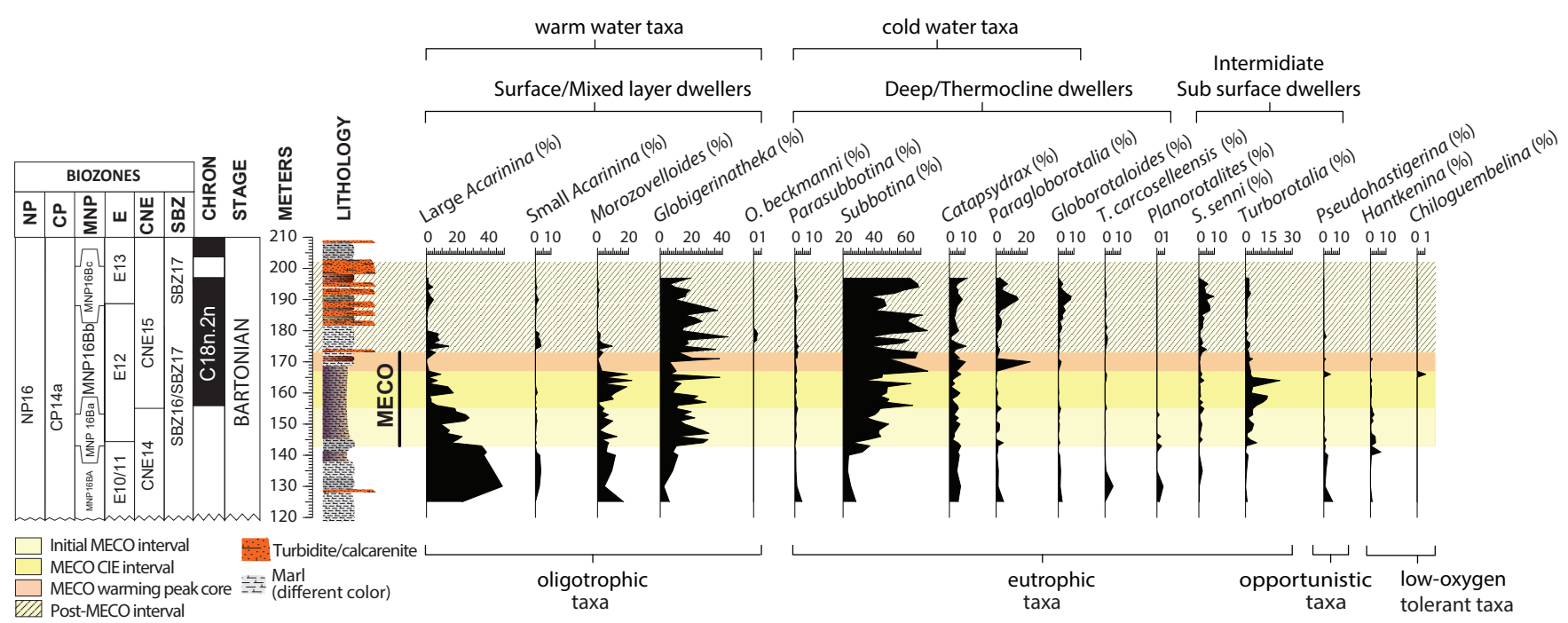

Figure 5. Relative abundance of middle Eocene planktic foraminiferal genera and selected species form the Baskil section. The main ecological preferences are also indicated (see text for explanations). Magneto-biostratigraphy and lithostratigraphy as in Figure 2.

\subsection{Calcareous Nannofossils}

Calcareous nannofossils are common to abundant and show good preservation in almost all the samples. Results of the quantitative analysis are presented in Figure 6 and Table S3. The assemblages are dominated by placoliths that account for nearly $80 \%$ in some samples, among these the most represented genera are Coccolithus, Cribrocentrum, Cyclicargolithus, Dictyococcites and Reticulofenestra. Other prominent genera are Sphenolithus and Discoaster, while Chiasmolithus and Helicosphaera are less frequent. The Coccolithaceae are mainly represented by the genera Coccolithus, Chiasmolithus and Ericsonia. The genus Coccolithus consists of C. pelagicus and C. eopelagicus. The abundance record of the group shows a slight increasing trend during the $\mathrm{MECO}$ and a peak of abundance in the postMECO (>25\%). The genus Chiasmolithus is represented by the species $C$. grandis and $C$. solitus, it occurs continuously showing a decreasing trend in the lower part of the MECO and an increasing trend in the upper part of the MECO just above the worming peak. Ericsonia formosa is continuously present showing rising abundances (up to $18 \%$ ) in the upper part of the interval studied. 


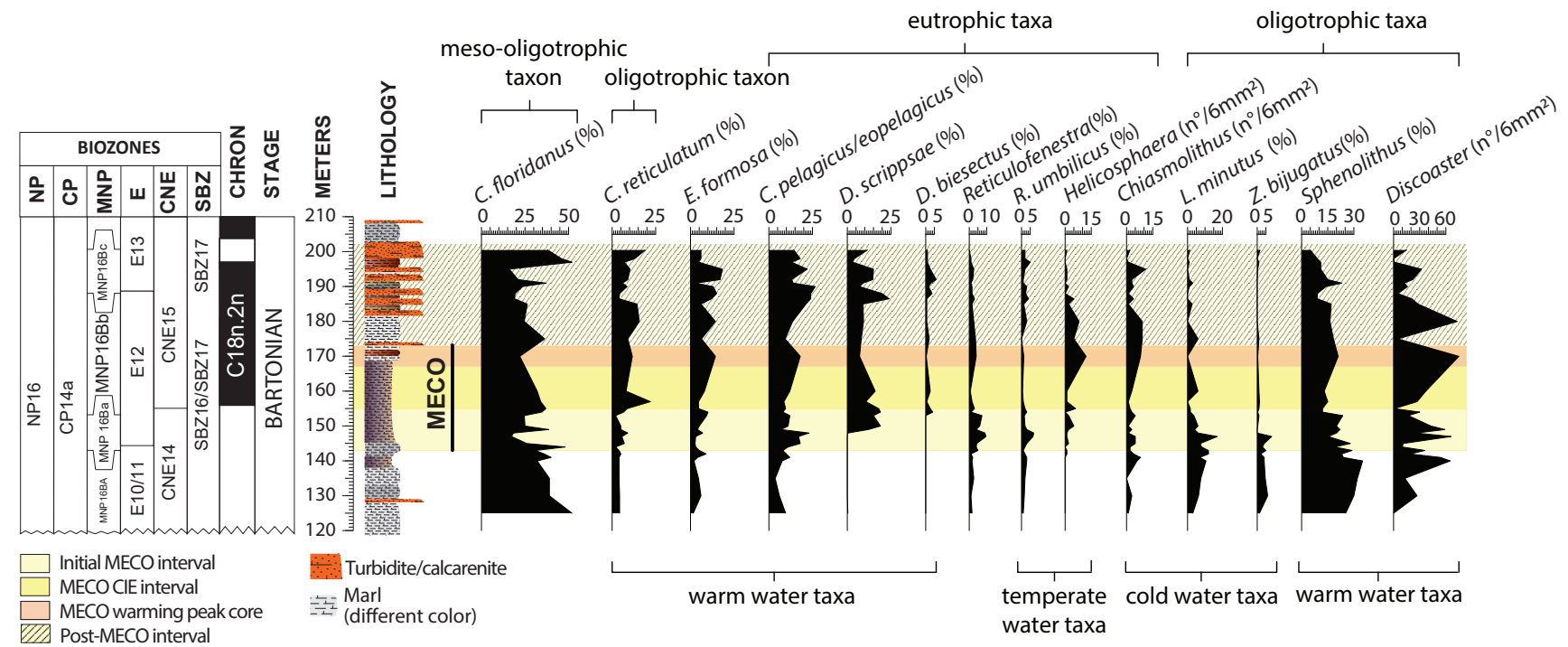

Figure 6. Abundances of middle Eocene planktic calcareous nannofossils genera and selected species from the Baskil section. The main ecological preferences are also indicated (see text for explanations). Magneto-biostratigraphy and lithostratigraphy as in Figure 2.

The Noelaerhabdaceae are represented by the genera Cribrocentrum, Cyclicargolithus, Dictyococcites and Reticulofenestra. Cribrocentrum shows increasing abundances in the middle part of the MECO. The genus Dictyococcites is represented by the species D. bisectus and D. scrippsae. Dictyococcites bisectus firstly occurs in the lower part of the MECO, while Dictyococcites scrippsae shows an abrupt variation in abundance (from $<1 \%$ to $>10 \%$ ) in the lower part of the MECO, later on it shows wider numerical changes. The genus Reticulofenestra comprises $R$. daviesii, $R$. dictyoda (specimens with length between 5 and $14 \mu \mathrm{m}$ ) and R. umbilicus (specimens with length $>14 \mu \mathrm{m}$ ). Both R. dictyoda and R. umbilicus show a peak of abundance in the lower part of the MECO (up to $>6 \%$ and $>16 \%$ respectively), followed by a decreasing trend in the upper part of the MECO. Reticulofenestra daviesii is very rare, sporadic, and not significant.

The genus Discoaster is represented by D. barbadiensis, D. deflandrei, D. nodifer, $D$. saipanensis, $D$. tani and by specimens of rayed stellate discoasters with prominent lateral nodes. Overall, the genus exhibits a clear increasing trend from below the onset of the MECO up to the post-MECO, but highly fluctuating values are also observed.

The genus Sphenolithus is represented by the species S. furcatolithoides, S. moriformis, S. obtusus, S. predistentus, S. radians and S. spiniger. The genus shows a significant decreasing trend in the lower part of the MECO followed by a rise in the upper part. Sphenolithus furcatolithoides disappears above the onset of the MECO, while S. spiniger shows higher abundances starting from below the MECO, and a drastic decreasing in the uppermost part of the MECO followed by its disappearance in the post- MECO interval.

The genus Helicosphaera is represented by the species H. compacta, H. euphratis, H. lophota, H. papillata, $H$. salebrosa, $H$. seminulum and $H$. wilcoxonii. The genus exhibits an increasing trend from the lower part of the MECO with a peak in abundance in its upper part.

The holococcoliths Lanternithus minutus and Zyghrablithus bijugatus show a rapid increase at the onset of the MECO with a peak in abundance in the lowermost part (respectively $17 \%$ and $\sim 8 \%$ ), followed by a drastic decrease in the upper part of the MECO and persisting low abundances in the post-MECO interval.

\section{Discussion}

The changes recorded in the biotic assemblages from the Baskil section together with the outcomes of statistical analysis (Table S4) and geochemical data allow us to identify five different phases across the investigated interval in relation to the main stable isotope shifts (Figure 7). Specifically, we recognize the following phases: pre-MECO, initial MECO, 
MECO CIE, MECO warming peak and post-MECO. The recognition of the environmental changes within these phases takes in account the known ecological preferences of the taxa identified, that we briefly summarize below.

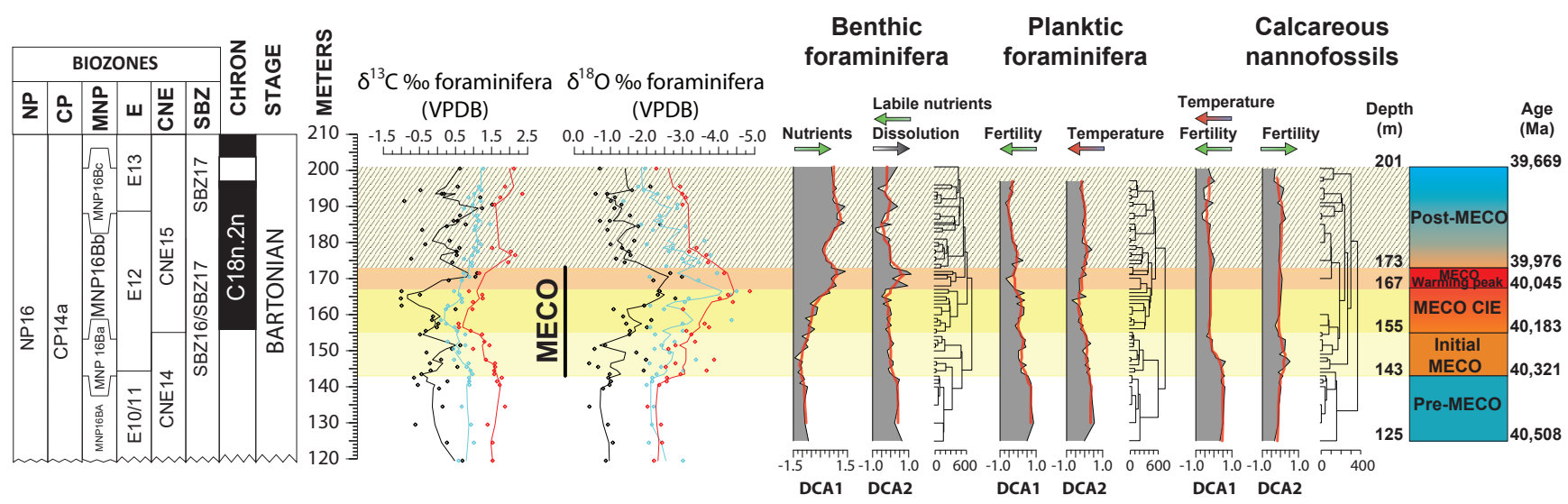

Figure 7. Changes in fertility, nutrients, temperature and carbonate dissolution as derived from the DCA analysis plotted next to the carbon and oxygen stable isotope curves. The inferred paleoenvironmental scenario for each phase is discussed in the text. Magneto-biostratigraphy and lithostratigraphy as in Figure 2.

\subsection{Middle Eocene Benthic Foraminifera Paleoecology}

Benthic foraminifera represent one of the most widely applied group of organisms in paleoceanographical and paleoenvironmental reconstructions along the geological record [73]. The investigation of the benthic foraminiferal record provides useful information on paleobathymetry, organic matter and oxygen availability at the seafloor [73]. Different investigations have focused on the response of benthic foraminiferal assemblages in terms of species and parameters across the MECO (e.g., [9,23,30,74-76]) and have supported the usefulness of benthic foraminifera for paleoenvironmental reconstructions.

The investigation of the benthic foraminiferal assemblages, species and indices (i.e., E/I, bi-triserial and diversity indices) at Baskil section coupled with isotopic records provides evidence of the paleoenvironmental changes at the seafloor but also of the dissolution intensity (i.e., P/B, C/A) across the MECO. The benthic foraminiferal assemblages are highly diversified and substantially very well preserved except in the most acute phase of the MECO. The inferred paleoecological preferences of benthic foraminiferal taxa are mainly based on $[9,23,74-76]$ and reference therein. The TROX model, a conceptual model for the definition of benthic foraminiferal microhabitat, identifies oxygen level in eutrophic environments and nutrient availability in oligotrophic among the most important parameters controlling the benthic foraminiferal distribution [77]. The percentages of epifaunal or infaunal specimens can provide useful clues on bottom-water oxygenation and nutrient availability among others [78]. Increases in the FI values, benthic over planktonic foraminiferal percentages and agglutinated over calcareous wall-type have been widely used as proxies of dissolution (i.e., [10]).

The genus Nuttallides and the species N. truempyi and N. umbonifera [51] are considered as epifaunal and oligotrophic indicator. Specifically, N. umbonifera and likely N. truempyi are inferred to reflect low and non-seasonal food supply (i.e., [51] and reference therein). In addition, Nuttallides truempyi has been also reported as intolerant to ocean acidification with a preference for well oxygenated conditions (i.e., [23] and reference therein). The Eocene Uvigerina spp. and Lenticulina spp. revealed to be tolerant to dysoxic-suboxic conditions thriving in oxygen depleted environments (i.e., [75] and reference therein). High abundances of bi-triserial taxa have been related to high and continuous nutrients' supply at the seafloor but also of less refractory nature (i.e., [9]). Oridorsalis umbonatus has been suggested to thrive in well oxygenated and low organic matter environments $([23,75]$ and 
reference therein). The deep infaunal Globobulimina species has been identified within ORG2 at the Alano section where markedly hypoxic conditions were inferred [9].

\subsection{Middle Eocene Planktic Foraminiferal Paleoecology}

Trophic and life strategies inferred for Eocene taxa derive from several studies based on large data set obtained from diverse latitudes, biogeographic distribution, environmental preferences as extensively discussed in numerous papers (e.g., $[18,61]$ and reference therein]), thus planktic foraminiferal paleoecology is rather well known. The stable isotope data available for most of species and genera allow us to decipher their habitat in the water column and whether they were symbiont-bearing or not. Therefore, the compositional and abundance changes of the planktonic foraminifera assemblages across the MECO interval from the Baskil section allow us to interpret the environmental modifications recorded.

The genera Acarinina and Morozovella were mixed-layer taxa that dominated the tropical and subtropical assemblages in late Paleocene to middle Eocene (with Morozovella preceding Morozovelloides) and became extinct close to the Bartonian/Priabonian boundary (e.g., [79]). Even though photosymbionts are not preserved in the fossil record, indirect evidence for their presence in planktic foraminifera of the past can be deciphered through the stable isotope composition of differently sized specimens (e.g., [62,80-88]). In fact, larger specimens support greater dinoflagellate symbiont density and enhanced photosynthetic activity remove preferentially the lighter ${ }^{12} \mathrm{C}$ isotope during photosynthesis, leaving adjacent water enriched in ${ }^{13} \mathrm{C}$, thus $\delta^{13} \mathrm{C}$ signature is higher with increasing test size (e.g., [89]). Such a relationship has provided supporting evidence of photosymbiotic activity in Morozovelloides and Acarinina (e.g., $[87,90,91])$. By contrast, the absence of test size $-\delta^{13} \mathrm{C}$ gradients in Subbotina specimens is consistent with asymbiotic ecology (e.g., [61,62,84,92-94]). The differences in the mean $\delta^{13} \mathrm{C}$ values for Morozovelloides and Acarinina with respect to Subbotina give evidence for different depth habitats. The relatively high $\delta^{13} \mathrm{C}$ values for the two former genera suggest a mixed-layer habitat, while relatively low $\delta^{13} \mathrm{C}$ values for the latter suggest a thermocline habitat (e.g., $[61,95,96]$ and references therein). We kept specimens of Subbotina senni separate from other subbotinids, because this taxon likely occupied a different habitat $[61,62,92,95]$. Specifically, S. senni is considered a mixed-layer form that sank to middle mixed-layer or deeper depths during gametogenesis (e.g., [61,62,92]). Turborotaliids display stable isotope signatures compatible with a sub-surface, possibly upper thermocline habitat (e.g., [92]), whereas Paragloborotalia, Catapsydrax, Globorotaloides and Turborotalita carcoselleensis are considered as deep thermocline dwellers (e.g., [61,92]).

Globigerinatheka is a symbiont-bearing mixed layer dweller [62,92,97], but stable isotope values commonly indicate calcification in deeper waters [74,98-101] suggesting that the genus had late-stage calcification, with $\mathrm{CaCO}_{3}$ crusts forming deeper in the water column $[92,100]$. The Globigerinatheka isotope records thus reflect conditions between the mixed layer and the thermocline [95,98,99], as also indicated by boron isotope data [102]. The genus Hantkenina is recognized as having inhabited the Oxygen Minimum Zone (OMZ) [61,103].

The general inferred stable isotope paleobiology and distribution of the biserial Chiloguembelina ascribe it as low-oxygen tolerant, meso- to eutrophic thermocline dweller thriving in stressed environmental conditions; Pseudohastigerina as well is known as opportunist taxon (e.g., [18,94,104-107]).

However, even though we are fairly well informed on middle Eocene planktic foraminifera ecology, the interpretation of changes in assemblages is not always straightforward due to the multiple factors influencing their successful or decline in marine environment. The knowledge of geochemical, benthic foraminiferal and calcareous nannofossil variations besides the planktic foraminiferal record can drive us to reconstruct a more convincing environmental scenario. 


\subsection{Middle Eocene Calcareous Nannofossil Paleoecology}

The ecological preferences of the middle Eocene calcareous nannofossils are not definitively known and sometimes contrasting interpretations are given also on the basis that a species/genus can change behaviour through time or privilege only one environmental factor. We list below the selected interpretations. Even though the calcareous nannofossil changes in abundance may be sometimes of complex interpretation, our results can shed light on the ecological preferences when environmental conditions are clearly established on the basis of geochemical evidence which highlights the main ecological controlling factors.

The species Dictyococcites scrippsae and D. bisectus have been considered adapted to warm and eutrophic waters [108-111] whereas Cribrocentrum reticulatum is viewed as a temperate $[112,113]$ and oligotrophic taxon $[110,113]$. The species $R$. dictyoda and R. umbilicus have affinity to eutrophic temperate water as suggested by [110]. The genus Sphenolithus seems better adapted to oligotrophic and warm-water conditions [114-119]. Following Toffanin et al. (2011), we regard Coccolithus floridanus as a meso-oligotrophic index. Likewise, also Lanternithus minutus and Zygrhablithus bijugatus have been considered as better adapted to oligotrophic waters $[114,115,117,120,121]$.

Finally, the ecological affinities of the genus Discoaster are well-established because it is commonly recognized as a warm and oligotrophic index [108,110,116,118,122,123].

\subsection{Pre-MECO Phase (120-142 m): Stratified Water Column and Oligotrophic Conditions}

The pre-MECO phase corresponds to the interval preceding the warming trend as documented by the oxygen stable isotopes (Figure 2). Benthic foraminiferal assemblages are characterized by high values of $\mathrm{P} / \mathrm{B}, \mathrm{C} / \mathrm{A}$, and diversity, and relatively low values of bi-triserial group (Figure 3). The relatively high abundance of the epifaunal group $(\sim 35 \%)$ likely suggests a low to moderate, flux of organic matter to the seafloor. This is also supported by the highest abundance of the epifaunal and oligotrophic indicator Nuttallides (i.e., N. truempyi and N. umbonifera) species (Figure 4, Table S1). The sea floor records well oxygenated conditions as indicated by the high diversity and by the abundance of Nuttallides truempyi (Figure 4, Table S1).

Planktic foraminiferal assemblages are well diversified in this interval (Figure 5). This indicates the occurrence of a stratified upper water column with all ecological niches occupied. Mixed-layer dwellers (Acarinina, Morozovelloides, Globigerinatheka), thermocline dwellers (Subbotina, Parasubbotina, Catapsydrax, Paragloborotalia,) and shallow sub-surface dwellers (intermediate between mixed-layer and thermocline) Turborotalia are in fact present. Planktic foraminiferal assemblages suggest oligotrophic surface-water because they contain abundant oligotrophic indices such as the symbiont-bearing large Acarinina (dominant), Morozovelloides and Globigerinatheka. A relatively expanded Oxygen Minimum Zone (OMZ) is suggested by the occurrence, though with low abundance, of Hantkenina. Oligotrophic conditions within the photic zone are also supported by relatively abundant Sphenolithus, L. minutus, Z. bijugatus, generally considered as oligotrophic indices (Figure 6).

In Figure 7, the statistical analysis highlights prevailing oligotrophic conditions both along the water column and at the seafloor. It also suggests overall cooler conditions and the absence of carbonate dissolution.

\subsection{The Initial MECO Phase (142-155 m): Rising of Mesotrophic Conditions}

During the INITIAL MECO Phase, which corresponds to the initial warming trend, as indicated by the $\delta^{18} \mathrm{O}$ curves (Figure 2), the variations in all the groups analyzed record the surface water temperature increase and a shift towards mesotrophic conditions throughout the water column. This is possibly related to the enhanced hydrological cycle and terrigenous flux as documented by geochemical proxies [32].

Benthic foraminiferal assemblages are characterized by a slight increase in bi-triserial taxa and E/I values and decrease of diversity (Figure 3). Although the increase in E/I values might suggest an overall decrease, in terms of quantity, of nutrient supply in 
the bottom, the increase in bi-triserial forms likely points to a change in the quality of organic matter (i.e., more labile) reaching the seafloor. This might also be expressed by the slight divergence of the $\delta^{13} \mathrm{C}$ curve of the Cibicidoides from those of the planktic genera of foraminifera in this interval.

Similar findings were reported for the initial phase of MECO at Alano section and interpreted as a shift from more oligotrophic to fully mesotrophic conditions [9]. The drastic decrease of Nuttalides and increase in Uvigerina spp. (Figure 4) at the Baskil section in this phase might suggest a reduction in oxygen availability at the sea floor. The decrease in the P/B, C/A and diversity indices (Figure 3) can be related with increase of carbonate dissolution.

A major change is recorded within planktic foraminiferal assemblages as the large Acarinina markedly decreased in abundance within this phase (Figure 5). Although this group is a warm index that should benefit of the warming increase, the drop in abundance is likely related to the arising mesotrophic conditions. This new trophic state may explain the apparently contradictory increase in abundance of the cold eutrophic index Subbotina.

Calcareous nannofossils assemblages record increase in abundance of the eutrophic taxa, namely C. pelagicus, Reticulofenestra, R. umbilicus and Helicosphaera and a concurrent decrease of the oligotrophic ones (i.e., Sphenolithus and Z. bijugatus) (Figure 6) thus confirming the transition towards mesotrophic conditions. These conditions are even more intensified in the upper part of this phase as suggested by the peak of the eutrophic $D$. scrippsae. The high abundance of the oligotrophic warm index Discoaster in this phase can be explained with a major sensitivity to the temperature increase of this genus.

The statistical analysis shown in Figure 7 clearly demonstrate as our biotic proxies reflect an increase in temperature along the water column, the transition to a mesotrophic state of surface water and a change in the quality of organic matter (i.e., more labile) reaching the seafloor.

\subsection{The MECO CIE Phase (155-167 m): Enhanced Eutrophic Conditions}

This phase corresponds to the main negative excursion of $\delta^{13} \mathrm{C}$ that is coupled with prominent rise in paleotemperatures (Figure 2). The MECO CIE phase is marked by a further increase in bi-triserial benthic foraminifera and a slight reduction in the E/I values (Figure 3). Such changes can be ascribed to enhanced organic matter availability to the seafloor both in terms of quantity and quality and a possible lowering of oxygen availability at the seafloor, as indicated by lowest values of Nuttalides spp. together with two peaks of Lenticulina spp. (Figure 4). This evidence agrees with a more stratified water column and consequent more efficient biological pump, as suggested by lower $\delta^{13} \mathrm{C}$ and higher difference in $\delta^{18} \mathrm{O}$ values between deep and surface dwelling planktic foraminifera [3]. This interval also shows a further decrease of $\mathrm{C} / \mathrm{A}$ values that would reflect enhanced carbonate dissolution at the sea floor [31] (Figure 3).

Planktic foraminiferal assemblages are characterized by a further decrease of large Acarinina and an increase of Subbotina. Change in salinity and increase eutrophic conditions related to freshwater input due to enhanced hydrological cycle could have negatively impacted the habitat of the specialized, oligotrophic mixed-layer dwellers acarininids. On the contrary, the eutrophic genus Subbotina may have benefitted by high delivery of food to the thermocline, and this could explain the apparent inconsistency of increase in this cold index. The enhanced hydrological cycle during this warm phase is recorded in the Baskil section through the mineralogical and sedimentological records indicating increasing the nutrient flux from land [32]. Even tough, as an effect of temperature and consumer starvation, the remineralization of organic matter in the water column may have been higher [124-127], as has been argued for the PETM [128], the nutrient supply at Baskil proved to have been great enough to reach the thermocline habitat of subbotinids and partially the seafloor. A remark concerns the short-term fluctuations in abundance of the planktic foraminiferal genera analyzed. As expected, the transient fluctuations in abundance of the warm indices Morozovelloides and acarininids that shared the same 
mixed-layer habitats are generally in phase whereas their fluctuations are out of phase with those of the thermocline cold index Subbotina (Figure 5). The short-term oscillations in abundance of the warm-index symbiont-bearing mixed-layer dweller Globigerinatheka are out of phase with those of subbotinids, as expected, but also with those of acarininids and Morozovelloides. A possible competition within the mixed-layer can explain the observed record. Alternatively, different ecological conditions between the upper mixed-layer, inhabited by acarininids and Morozovelloides, and the deeper mixed-layer or uppermost thermocline, possibly inhabited by Globigerinatheka in its later stage of life, can justify its variation in abundance out-of-phase with respect to acarininids and Morozovelloides.

Among the calcareous nannofossil assemblages, the high relative abundance of D. scrippsae, already recorded in the upper part of the previous phase, may be the consequence of eutrophic conditions triggered by the great availability of nutrients. Warm and eutrophic conditions could have also stimulated the first common and continuous occurrence of $D$. bisectus that was only sporadically detected during the time interval below the MECO and recorded as more common at middle latitudes [108,129]. Although the species Cribrocentrum reticulatum has been considered a temperate and oligotrophic taxon, the increasing trend in abundance observed during this phase in the Baskil section, suggests that this species could have been adapted to eutrophic conditions.

The statistical analysis shown clearly sum up the environmental changes occurred during this phase such as increased temperature and fertility due to enhanced nutrient availability both in surface water and at the sea floor. The DCA2 curve of calcareous nannofossil indicators of fertility only partially displays the increasing trend due to the lower sampling resolution in this phase (Figure 7).

\subsection{The MECO Warming Peak Phase (167-173 m): Maximum of Surface-Water Nutrients and Dissolution}

The most striking biotic changes occurred, as expected, at the MECO WARMING PEAK marking the highest carbonate dissolution interval (Figures 2 and 3 ).

The benthic foraminiferal assemblages record the lowest $\mathrm{P} / \mathrm{B}, \mathrm{C} / \mathrm{A}$ and diversity values and the highest FI, bi-triserial forms and E/I values (Figure 3). These data reflect the peak of carbonate dissolution at the sea-floor as evidenced by a poor preservation state of foraminiferal tests and their fragmentation. This is also supported by the increase of agglutinated forms that are less prone to dissolution compared to the calcareous counterpart. In this interval, a marked increase in Cibicidoides spp. is observed (Figure 4). Increasing value of Cibicidoides spp. has been also documented during the most acute phase of MECO at Alano section and related to its higher resistant capability to dissolution being heavily calcified [9]. On the basis of the E/I and bi-triserial values, this interval likely denotes a decrease in the quantity of organic matter reaching the seafloor but likely an increase in its quality (i.e., labile).

Planktic foraminifera variations include the virtual disappearance of the oligotrophic planktic foraminiferal large Acarinina and Morozovelloides, and peak in eutrophic deep dwellers Subbotina (Figure 5). The striking reduction in abundance of large Acarinina and Morozovelloides can be explained through diverse factors. The first explanation of the observed 'eclipse', if not related to dissolution (see below), can be related to increased surface-water trophism that may have caused a reduction of the ecological niches in the mixed-layer thus excluding the meso-oligotrophic assemblages. Nevertheless, the marked temperature increase could have temporarily caused the loss of algal symbiont relationship (bleaching), as recorded by [20] at the MECO peak from ODP sites 748 and 1051 (Southern Ocean and mid-latitude North Atlantic) for the genus Acarinina, even though $\mathrm{pH}$ reduction and nutrient availability may also have played a role in the recorded bleaching [20]. We cannot however exclude that the high dissolution recorded in this interval might have differentially affected the large Acarinina and Morozovelloides, thus suggesting a second possible explanation. Petrizzo et al. [130] designate the cold deep-dwelling Subbotina as the most dissolution-susceptible taxon with respect to the muricate warm surface-dwellers Morozovella and Acarinina, as the results from analysis of the single fragments at the equato- 
rial Pacific Ocean assemblages (latest Paleocene to initial middle Eocene). Therefore, any Paleogene assemblages affected by extensive dissolution are expected to be impoverished in the most dissolution-susceptible subbotinids. In contrast, at the Alano section, the intervals with the highest fragmentation index display the largest relative percentages of subbotinids [18]. It is, therefore, possible that middle Eocene species of Subbotina here investigated were more robust forms and less prone to dissolution than the older ones investigated by [130]. The peak in abundance of cold-indices subbotinids can be read as their primary response to the trophic level rather than a response to temperature, as inferred for the previous MECO phases. Their increase in abundance is recorded even in the preceding intervals, where dissolution was lower. This evidence points towards a minor influence of dissolution thus suggesting that dissolution probably only exacerbated the original planktic foraminiferal response to the MECO peak. In this regard, the marked reduction in Globigerinatheka, that has robust shell thus potentially dissolution-resistant, is likely related to the environmental MECO perturbation rather than to dissolution effects. The record of planktic foraminiferal assemblages from the Alano section [18] shows a similar decline in large Acarinina and Morozovelloides and increase of subbotinids. However, in the Alano section the strong increase of opportunist taxa (i.e., Pseudohastigerina, chiloguembelinids, Jenkinsina) indicates a much more stressed and extremely eutrophic environment with respect to Baskil [18].

Calcareous nannofossil variations likely derive in this phase from a combined result of the warming peak, as indicted by increase of C. pelagicus, C. reticulatum, E. formosa, Discoaster, Sphenolithus and by the highest eutrophic state that induced increased abundance of Helicosphaera and C. pelagicus. The reduction of the eutrophic C. floridanus and D. scrippsae could be explained by a more sensitivity of these species to enhanced carbonate dissolution [131] (Figure 6).

The peak of nutrient to the sea floor and upper water column fertility is coupled to the record by the calcareous plankton of the maximum temperature (Figure 7). In this interval, the interpretation of DCA 1 and 2 of the benthic foraminiferal assemblages is complex and made difficult by the dissolution that had altered the original benthic foraminiferal assemblage composition.

\subsection{The Post-MECO Phase (173-201 m): Partial Recovery of the Pre-Event Conditions}

This phase, which corresponds to the $\delta^{18} \mathrm{O}$ values recovery, shows a recovery in the benthic foraminiferal assemblages marked by an increase in $\mathrm{P} / \mathrm{B}$ and $\mathrm{C} / \mathrm{A}$ values that can be ascribed to the end of the dissolution phase (Figure 3). This interval is also characterized by a marked reduction of the E/I and bi-triserial forms and would therefore reflect higher availability of organic matter but likely refractory in origin (Figure 3). The final part of the post-MECO interval (i.e., 181-201 m) exhibits some peculiar feature such as the occurrence of radiolarians with a peak in abundance from 183 to $185.5 \mathrm{~m}$ that can suggest a transient increase of eutrophic conditions (e.g., [132]). Interestingly, the benthic foraminiferal assemblages around 188-190 m record the lowest value of $\mathrm{P} / \mathrm{B}, \mathrm{C} / \mathrm{A}$ and diversity. In this short interval, the lowest value of bi-triserial forms is associated to relatively high value of $\mathrm{E} / \mathrm{I}$.

The planktic foraminiferal assemblages shows a major long-term change as large Acarinina and Morozovelloides do not recover their abundance in this phase that should record the recovery, at least in part, of the pre-event conditions (Figure 5). The results from the Baskil section emphasize that a first abrupt decline in abundance of the large acarininids and morozovellids took place well before their evolutionary extinction level occurred at the Bartonian-Priabonian boundary. Our data confirm other records from Tethyan sections of northern Italy $[18,19]$ and tropical Atlantic [20]. Although test size $-\delta^{13} \mathrm{C}$ gradients are not available from the Tethyan/Neo-Tethyan successions, the permanent loss of algal photosymbiont-relationship does not appear as the main cause of the permanent reduction in abundance of these groups. On the other hand, the bleaching recorded by [20] revealed to be a transient episode because the symbiotic relationship was recovered after 
the MECO peak. The causes of this persisting decline in abundance are not yet established, however, a link to the climatic change and paleoceanographic variations that occurred during the MECO or just following it seems implied. The irreversible return towards cooling conditions after the MECO that culminated with the onset of icehouse condition at the Eocene-Oligocene boundary may have played a role, taking in account that both large acarininids and Morozovelloides were warm-indices. This evidence might explain the decline at the tropical Atlantic and Tethys successions. Possibly local/regional conditions at the Baskil geological setting induced an earlier large acarininids decline in abundance at the MECO beginning. The Baskil section deposited in relatively restricted hemipelagic conditions [33]. The increased sedimentation rates indicate enhanced hydrological cycle in a warmer and more humid climate on land since the beginning of the MECO as it is proved also by increase in smectite/illite ratios, terrigenous elements (e.g., Fe, Ti and $\mathrm{Al}$ ) [32]. The Neo-Tethys in the middle Eocene was a narrow basin with a complex topography, similar to the Mediterranean Sea [133]. Therefore, the continental runoff delivered significant amounts of light carbon and fresh water [3]. Change in salinity and increase trophism related to freshwater input could have negatively impacted the habitat of the specialized, oligotrophic mixed-layer dwellers, such as large acarininids and Morozovelloides during the MECO at Baskil. Afterwards, their permanent decline may have been driven by global climatic and paleoceanographic variations. Even though the mixed-layer was deprived of these two groups, the upper water-column appears still stratified during the MECO and afterward. It is possible that the increase of Subbotina senni might be explained, at least in part, with its colonizing the ecological niches released by acarininids. Similar behaviour may have been adopted by Globigerinatheka. As expected, the thermocline dweller, coldindices Subbotina and Globorotaloides increase in abundance in the post-MECO interval when temperature decreased suggesting that in this phase these genera mainly benefit of the cooler temperatures.

The calcareous nannofossil record in this phase appears once more controlled both by the temperature and trophic state. In fact, the warm indices Sphenolithus, C. reticulatum and Discoaster show a reduction in abundance, compatible with the cooling trend, even though only a moderate increase of the cold index Chiasmolithus is recorded (Figure 6). The increase of the warm but also eutrophic indices C. pelagicus / C. eopelagicus, E. formosa and D. scrippsae can be ascribed to persisting, although fluctuating, eutrophic conditions. The occurrence of eutrophic radiolarians possibly linked to input of nutrients related to the turbidites in this interval suggests that transient eutrophic phases interrupted the recovery of meso-oligotrophic conditions in the photic zone.

The aforementioned environmental variations occurred in Baskil in the post-MECO phase are well expressed by the statistical analysis (Figure 7) that shows the dissolution decrease and the response of calcareous plankton to the decreasing temperature but still highlights pulses of high fertility as recorded by calcareous nannofossils. Benthic foraminifera document higher availability of organic matter but likely refractory in origin.

\section{Summary and Conclusions}

We here provide the results of the integrated high-resolution analysis of changes in benthic foraminifera and calcareous plankton assemblages across the MECO event from the Neo-Tethyan Baskil section. The combinations of these records integrated with geochemical variations and supported by a statistical approach (detrended correspondence analyses, DCA) allows us to outline five phases of the main environmental scenarios across the interval investigated (Figure 7). The pre-MECO phase, when prevailed cooler conditions, was characterized by a well-stratified water column and oligotrophic state throughout the water column. During the INITIAL MECO phase variations in all the analyzed groups record a temperature increase as sustained by a negative $\delta^{18} \mathrm{O}$ shift. A change towards mesotrophic conditions occurred in this phase, possibly related to the enhanced hydrological cycle and terrigenous flux as documented by geochemical and mineralogical proxies. Changes in benthic foraminifera and diversity indices point to an 
increased dissolution at the sea floor. The variations in geochemical proxies and biotic changes across the MECO CIE phase testify persistent high surface water temperature and the establishment of eutrophic conditions throughout the water column. The seafloor was characterized by enhanced organic matter availability both in terms of quantity and quality and a possible lowering of oxygen availability. This interval also shows a further decrease of $\mathrm{C} / \mathrm{A}$ values that reflect enhanced carbonate dissolution. The MECO WARMING PEAK interval is marked by the most striking biotic changes that record a response to the warming and to eutrophication as testified by peak in abundance of the warm and eutrophic nannofossils indices, virtual disappearance of the oligotrophic planktic foraminifera and peak in eutrophic deep dwellers taxa. On the basis of the E/I and bi-triserial benthic foraminiferal values, this interval likely denotes a decrease in the quantity of organic matter reaching the seafloor but likely an increase in its quality (i.e., labile). This phase also reflects peak in carbonate dissolution that may have amplified the original planktic foraminiferal response. During the gradual recovery of oxygen stable isotope values towards the pre-event record, the post-MECO phase highlights only a partial return to the pre-event mesotrophic conditions. Actually, our biotic data demonstrate that the entire water column remained somehow affected by the MECO conditions, possibly due to the combined effect of local factors and global climate. This is suggested by a slight return to more proportionated percentages of oligo- and eutrophic calcareous nannofossils indices. However, transient eutrophic conditions are testified by calcareous nannofossil eutrophic taxa that show peaks in abundance at the top of this interval. This is possibly related to nutrients input associated to the resedimented levels occurring in this phase. The occurrence of the eutrophic radiolarians confirms the fluctuating eutrophic state. Planktic foraminiferal assemblages became relatively more diversified though dominated by cold eutrophic thermocline dwellers. The results from the Baskil section emphasize that a first abrupt permanent decline in abundance of the large acarininids and morozovellids took place well before their evolutionary extinction level occurring at the Bartonian/Priabonian boundary. Our data agree with other records from Tethyan sections of northern Italy and tropical Atlantic. A recovery during the post-MECO phase is recorded by benthic foraminiferal assemblages and indices. Specifically, a general reduction of the E/I and bi-triserial forms reflect higher availability of organic matter onto the sea floor but likely refractory in origin, whereas overall increased $\mathrm{P} / \mathrm{B}$ and $\mathrm{C} / \mathrm{A}$ values mark the end of the dissolution phase. In conclusion, the proposed scenarios reveal how paleoenvironment and marine biota from the studied Neo-Tethyan setting reacted to the global MECO perturbation recording transient and permanent changes and show more evidence on the still enigmatic MECO event.

Supplementary Materials: The following are available online at https:/ /www.mdpi.com/article/10 .3390/app112311339/s1, Table S1: benthic foraminiferal indices and abundances; Table S2: planktic foraminiferal abundances; Table S3: calcareous nannofossil abundances; Table S4: detrended correspondence analysis (DCA) results.

Author Contributions: Conceptualization, R.D., F.F. (Fabrizio Frontalini), V.L., R.C. and L.J.; Data curation, R.D.; Formal analysis, R.D., A.S.Z., F.F. (Fabrizio Frontalini), V.L., R.C. (Rita Catanzariti) and F.F. (Fabio Francescangeli); Methodology, R.D., A.S.Z., F.F. (Fabrizio Frontalini), V.L., R.C. and F.F. (Fabio Francescangeli); Supervision, F.F. (Fabrizio Frontalini), V.L., R.C. (Rodolfo Coccioni) and L.J.; Validation, R.D., A.S.Z., F.F. (Fabrizio Frontalini), V.L., R.C. (Rita Catanzariti), F.F. (Fabio Francescangeli), M.G., R.C. (Rodolfo Coccioni), E.Ö. and L.J; Visualization, R.D.; Writing-original draft, R.D., F.F. (Fabrizio Frontalini), V.L., R.C. (Rita Catanzariti), F.F. (Fabio Francescangeli) and L.J.; Writing一review \& editing, R.D., A.S.Z., F.F. (Fabrizio Frontalini), V.L., R.C. (Rita Catanzariti), F.F. (Fabio Francescangeli), M.G., R.C. (Rodolfo Coccioni), E.Ö. and L.J. All authors have read and agreed to the published version of the manuscript.

Funding: Funding for this research was provided for V.L. and R.D. by the Cofinanziamento MIUR (Italian Ministero dell'Istruzione, dell'Universita' e Ricerca) P.R.I.N. (Progetti di Ricerca di interesse nazionale to V. LUCIANI (within a National Research Project coordinated by E. Erba, Milan University, Italy, P.R.I.N. 2017, 2017RX9XXXY “Biota Resilience to Global Change: Biomineralization of Planktic 
and Benthic Calcifiers in the Past, Present and Future" and by the Ferrara University (FAR -Fondo Ateneo Ricerca-Luciani 2020 and 2021). This research is supported by the FAPESP (Fundação de Amparo à Pesquisa do Estado de São Paulo-Process No. 2016/24946-9). F. Fra. was supported by the Alexander von Humboldt Foundation (Ref 3.3-ITA-1203503-HFST-P).

Data Availability Statement: Data supporting this paper are available in Table S1, Table S2, Table S3, Table S4 in the Supplementary Materials.

Acknowledgments: We thanks the reviewer for the constructive suggestions that improved the manuscript.

Conflicts of Interest: The authors declare no conflict of interest.

\section{References}

1. Bohaty, S.M.; Zachos, J.C.; Florindo, F.; Delaney, M.L. Coupled greenhouse warming and deep-sea acidification in the middle Eocene. Paleoceanography 2009, 24, PA2207. [CrossRef]

2. Westerhold, T.; Röhl, U. Orbital pacing of Eocene climate during the Middle Eocene Climate Optimum and the chron C19r event: Missing link found in the tropical western Atlantic. Geochem. Geophys. Geosyst. 2013, 14, 4811-4825. [CrossRef]

3. Giorgioni, M.; Jovane, L.; Rego, E.S.; Rodelli, D.; Frontalini, F.; Coccioni, R.; Catanzariti, R.; Özcan, E. Carbon cycle instability and orbital forcing during the Middle Eocene Climatic Optimum. Sci. Rep. 2019, 9, 9357. [CrossRef] [PubMed]

4. Kochhann, M.V.L.; Savian, J.F.; Tori, F.; Catanzariti, R.; Coccioni, R.; Frontalini, F.; Jovane, L.; Florindo, F.; Monechi, S. Orbital tuning for the middle Eocene to early Oligocene Monte Cagnero Section (Central Italy): Paleoenvironmental and paleoclimatic implications. Palaeogeogr. Palaeoclimatol. Palaeoecol. 2021, 577, 110563. [CrossRef]

5. Bohaty, S.M.; Zachos, J.C. Significant Southern Ocean warming event in the late middle Eocene. Geology 2003, 31, 1017-1020. [CrossRef]

6. Jovane, L.; Florindo, F.; Coccioni, R.; Dinarès-Turell, J.; Marsili, A.; Monechi, S.; Roberts, A.P.; Sprovieri, M. The middle Eocene climatic optimum event in the Contessa Highway section, Umbrian Apennines, Italy. Geol. Soc. Am. Bull. 2007, 119, 413-427. [CrossRef]

7. $\quad$ Edgar, K.M.; Wilson, P.A.; Sexton, P.F.; Gibbs, S.J.; Roberts, A.P.; Norris, R.D. New biostratigraphy, magnetostratigraphy and isotopic insights into the Middle Eocene Climatic Optimum in low latitudes. Palaeogeogr. Palaeoclimatol. Palaeoecol. 2010, 297, 670-682. [CrossRef]

8. Spofforth, D.J.A.; Agnini, C.; Pälike, H.; Rio, D.; Fornaciari, E.; Giusberti, L.; Luciani, V.; Lanci, L.; Muttoni, G. Organic carbon burial following the middle Eocene climatic optimum in the central western Tethys. Paleoceanography 2010, 25, PA3210. [CrossRef]

9. Boscolo Galazzo, F.; Giusberti, L.; Luciani, V.; Thomas, E. Paleoenvironmental changes during the Middle Eocene Climatic Optimum (MECO) and its aftermath: The benthic foraminiferal record from the Alano section (NE Italy). Palaeogeogr. Palaeoclimatol. Palaeoecol. 2013, 378, 22-35. [CrossRef]

10. Savian, J.F.; Jovane, L.; Frontalini, F.; Trindade, R.I.F.; Coccioni, R.; Bohaty, S.M.; Wilson, P.A.; Florindo, F.; Roberts, A.P.; Catanzariti, R.; et al. Enhanced primary productivity and magnetotactic bacterial production in response to middle Eocene warming in the Neo-Tethys Ocean. Palaeogeogr. Palaeoclimatol. Palaeoecol. 2014, 414, 32-45. [CrossRef]

11. Bijl, P.K.; Houben, A.J.P.; Schouten, S.; Bohaty, S.M.; Sluijs, A.; Reichart, G.-J.; Damsté, J.S.S.; Brinkhuis, H. Transient Middle Eocene atmospheric $\mathrm{CO}_{2}$ and temperature variations. Science 2010, 330, 819-821. [CrossRef]

12. Sluijs, A.; Zeebe, R.E.; Bijl, P.K.; Bohaty, S.M. A middle Eocene carbon cycle conundrum. Nat. Geosci. 2013, 6, 429-434. [CrossRef]

13. Borelli, C.; Cramer, B.S.; Katz, M.E. Bipolar Atlantic deepwater circulation in the middle late Eocene: Effects of Southern Ocean gateway openings. Paleoceanography 2014, 29, 308-327. [CrossRef]

14. George, R.; Rogers, N.; Kelley, S. Earliest magmatism in Ethiopia: Evidence for two mantle plumes in one flood basalt province. Geology 1998, 26, 923-926. [CrossRef]

15. Aguirre-Diaz, G.J.; Labarthe-Hernandez, G. Fissure ignimbrites: Fissure-source origin for voluminous ignimbrites of the Sierra Madre Occidental and its relationship with Basin and Range faulting. Geology 2003, 31, 773-776. [CrossRef]

16. Bowen, G.J.; Zachos, J.C. Rapid carbon sequestration at the termination of the Palaeocene-Eocene Thermal Maximum. Nat. Geosci. 2010, 3, 866-869. [CrossRef]

17. Beniamovski, V.N.; Alekseev, A.S.; Ovechkina, M.N.; Oberhänsli, H. Middle to Upper Eocene disoxic-anoxic Kuma Formation (northeast Peri-Tethys): Biostratigraphy and paleoenviroments. In Causes and Consequences of Globally Warm Climates in the Early Paleogene; Wing, S.L., Ed.; Geological Society of America: Boulder, CO, USA, 2003; Volume 369, pp. 95-112.

18. Luciani, V.; Giusberti, L.; Agnini, C.; Fornaciari, E.; Rio, D.; Spofforth, D.J.A.; Pälike, H. Ecological and evolutionary response of Tethyan planktonic foraminifera to the middle Eocene climatic optimum (MECO) from the Alano section (NE Italy). Palaeogeogr. Palaeoclimatol. Palaeoecol. 2010, 292, 82-95. [CrossRef]

19. Luciani, V.; Fornaciari, E.; Papazzoni, C.A.; Dallanave, E.; Giusberti, L.; Stefani, C.; Amante, E. Integrated stratigraphy at the Bartonian-Priabonian transition: Correlation between shallow benthic and calcareous plankton zones (Varignano section, northern Italy). Geol. Soc. Am. Bull. 2020, 132, 495-520. [CrossRef] 
20. Edgar, K.M.; Bohaty, S.M.; Gibbs, S.J.; Sexton, P.F.; Norris, R.D.; Wilson, P.A. Symbiont 'bleaching' in planktic foraminifera during the Middle Eocene Climatic Optimum. Geology 2013, 41, 15-18. [CrossRef]

21. Toffanin, F.; Agnini, C.; Fornaciari, E.; Rio, D.; Giusberti, L.; Luciani, V.; Spofforth, D.J.A.; Pälike, H. Changes in calcareous nannofossil assemblages during the Middle Eocene Climatic Optimum: Clues from the central-western Tethys (Alano section, NE Italy). Mar. Micropaleontol. 2011, 81, 22-31. [CrossRef]

22. Moebius, I.; Friedrich, O.; Edgar, K.M.; Scher, H.D.; Sexton, P. Bottom water changes in the subtropical North Atlantic and the Southern Ocean associated to the Middle Eocene Climatic Optimum. In Proceedings of the AGU Fall Meeting 2013, San Francisco, CA, USA, 9-13 December 2013.

23. Moebius, I.; Friedrich, O.; Scher, H.D. Changes in Southern Ocean bottom water environments associated with the Middle Eocene Climatic Optimum (MECO). Palaeogeogr. Palaeoclimatol. Palaeoecol. 2014, 405, 16-27. [CrossRef]

24. Witkowski, J.; Bohaty, S.M.; McCartney, K.; Harwood, D.M. Enhanced siliceous plankton productivity in response to middle Eocene warming at Southern Ocean ODP Sites 748 and 749. Palaeogeogr. Palaeoclimatol. Palaeoecol. 2012, 326-328, 78-94. [CrossRef]

25. Witkowski, J.; Bohaty, S.M.; Edgar, K.M.; Harwood, D.M. Rapid fluctuations in mid-latitude siliceous plankton production during the Middle Eocene Climatic Optimum (ODP Site 1051, western North Atlantic). Mar. Micropaleontol. 2014, 106, 110-129. [CrossRef]

26. Villa, G.; Fioroni, C.; Persico, D.; Roberts, A.P.; Florindo, F. Middle Eocene to Late Oligocene Antarctic glaciation/deglaciation and Southern Ocean productivity. Paleoceanography 2014, 29, 223-237. [CrossRef]

27. Lyle, M.; Lyle Olivarez, A.; Backman, J.; Tripati, A. Biogenic sedimentation in the Eocene equatorial Pacific-The stuttering greenhouse and Eocene carbonate compensation depth. In Proceedings of the Ocean Drilling Program, Scientific Results; Wilson, P.A., Lyle, M., Firth, J.V., Eds.; Ocean Drilling Program: College Station, TX, USA, 2005; Volume 199, pp. 1-35. [CrossRef]

28. Lyle, M.; Barron, J.; Bralower, T.J.; Huber, M.; Olivarez Lyle, A.; Ravelo, A.C.; Rea, D.K.; Wilson, P.A. Pacific Ocean and Cenozoic evolution of climate. Rev. Geophys. 2008, 46, RG2002. [CrossRef]

29. Pea, L. Eocene-Oligocene Paleoceanography of the Subantarctic South Atlantic: Calcareous Nannofossil Reconstructions of Temperature, Nutrient, and Dissolution History. Ph.D. Thesis, Dipartimento di Scienze della Terra, Università degli Studi di Parma, Parma, Italy, 2011.

30. Takata, H.; Nomura, R.; Tsujimoto, A.; Khim, B.; Chung, I. Abyssal benthic foraminifera in the eastern equatorial Pacific (IODP exp 320) during the Middle Eocene. J. Paleontol. 2013, 87, 1160-1185. [CrossRef]

31. Cornaggia, F.; Bernardini, S.; Giorgioni, M.; Silva, G.L.X.; Nagy, A.I.M.; Jovane, L. Abyssal Oceanic Circulation and Acidification during the Middle Eocene Climatic Optimum (MECO). Sci. Rep. 2020, 10, 6674. [CrossRef]

32. Rego, E.R.; Jovane, L.; Hein, J.R.; Sant'Anna, L.G.; Giorgioni, M.; Rodelli, D.; Özcan, E. Mineralogical evidence for warm and dry climatic conditions in the Neo-Tethys (eastern Turkey) during the middle Eocene. Palaeogeogr. Palaeoclimatol. Palaeoecol. 2018, 501, 45-57. [CrossRef]

33. Rodelli, D.; Jovane, L.; Özcan, E.; Giorgioni, M.; Coccioni, R.; Frontalini, F.; Rego, E.S.; Brogi, A.; Catanzariti, R.; Less, G.; et al. High-resolution integrated magnetobiostratigraphy of a new middle Eocene section from the Neotethys (Elazı̆ Basin, eastern Turkey). Geol. Soc. Am. Bull. 2018, 130, 193-207. [CrossRef]

34. Martini, E. Standard Tertiary and Quaternary calcareous nannoplankton zonation. In Proceedings of the 2nd Planktonic Conference, Rome, Italy, 1970; Farinacci, A., Ed.; Tecnoscienza: Rome, Italy, 1971; Volume 2, pp. 739-785.

35. Okada, H.; Bukry, D. Supplementary modification and introduction of code numbers to the low-latitude coccolith biostratigraphic zonation (Bukry, 1973; 1975). Mar. Micropaleontol. 1980, 5, 321-325. [CrossRef]

36. Fornaciari, E.; Agnini, C.; Catanzariti, R.; Rio, D.; Bolla, E.M.; Valvasoni, E. Mid-latitude calcareous nannofossil biostratigraphy and biochronology across the middle to late Eocene transition. Stratigraphy 2010, 7, 229-264.

37. Agnini, C.; Fornaciari, E.; Raffi, I.; Catanzariti, R.; Pälike, H.; Backman, J.; Rio, D. Biozonation and biochronology of Paleogene calcareous nannofossils from low and middle latitudes. Newsl. Stratigr. 2014, 47, 131-181. [CrossRef]

38. Wade, B.S.; Pearson, P.N.; Berggren, W.A.; Pälike, H. Review and revision of Cenozoic tropical planktonic foraminiferal biostratigraphy and calibration to the geomagnetic polarity and astronomical time scale. Earth-Sci. Rev. 2011, 104, 111-142. [CrossRef]

39. Serra-Kiel, J.; Hottinger, L.; Caus, E.; Drobne, K.; Ferràndez, C.; Jauhri, A.K.; Less, G.; Pavlovec, R.; Pignatti, J.; Samsó, J.M.; et al. Larger foraminiferal biostratigraphy of the Tethyan Paleocene and Eocene. Bull. Société Géologique Fr. 1998, 169, $281-299$.

40. Less, G.; Özcan, E. Bartonian-Priabonian larger benthic foraminiferal events in the Western Tethys. Mitt. Osterr. Geol. Ges. 2012, $105,129-140$.

41. Özcan, E.; Less, G.; Báldi-Beke, M.; Kollányi, K.; Kertesz, B. Biometric analysis of middle and upper Eocene Discocyclinidae and Orbitoclypeidae (Foraminifera) from Turkey and updated orthophragmine zonation in the Western Tethys. Micropaleontology 2006, 52, 485-520. [CrossRef]

42. Özcan, E.; Less, G.; Jovane, L.; Catanzariti, R.; Frontalini, F.; Coccioni, R.; Giorgioni, M.; Rodelli, D.; Rego, E.S.; Kay ğ1l, S.; et al. Integrated biostratigraphy of the middle to upper Eocene Kırkgeçit Formation (Baskil Section, Elazığ, Eastern Turkey): Larger benthic foraminiferal perspective. Mediterr. Geosci. Rev. 2019, 1, 55-90. [CrossRef]

43. Çelik, H. The effects of linear coarse-grained slope channel bodies on the orientations of fold developments: A case study from the Middle Eocene-Lower Oligocene Kırkgeçit Formation, Elazı ̆̆, eastern Turkey. Turk. J. Earth Sci. 2013, 22, 320-338. [CrossRef] 
44. Ogg, J.G. Geomagnetic polarity time scale. In The Geologic Time Scale 2012, 1st ed.; Gradstein, F.M., Ogg, J.G., James, G., Schmitz, M.D., Ogg, G.M., Eds.; Elsevier: Amsterdam, The Netherlands, 2012; pp. 85-113. [CrossRef]

45. Lirer, F. A new technique for retrieving calcareous microfossils from lithified lime deposits. Micropaleontology 2000, 46, 365-369.

46. Loeblich, A.R.; Tappan, H. Foraminiferal Genera and their Classification. Van Nostrand Reinhold Company: New York, U.S.A., 1988 [year of publication often cited erroneously as 1987; see Loeblich, A.R., Tappan, H., Publication date of foraminiferal genera and their classification. J. Paleontol. 1989, 63, 253. [CrossRef]

47. Tjalsma, R.C.; Lohmann, G.P. Paleocene-Eocene Bathyal and Abyssal Benthic Foraminifera from the Atlantic Ocean. Micropaleontol. Spec. Pub. 1983, 4, 1-90.

48. Van Morkhoven, F.P.C.M.; Berggren, W.A.; Edwards, A.S. (Eds.) Cenozoic Cosmopolitan Deep-Sea Benthic Foraminifera; Bulletin du Centre de Recherches Exploration-Production Elf-Aquitaine Mémoire: Pau, France, 1986; Volume 11, p. 421.

49. Bolli, H.; Beckmann, J.; Saunders, J. Benthic Foraminiferal Biostratigraphy of the South. Caribbean Region, 1st ed.; Cambridge University Press: Cambridge, UK, 1994; p. 146.

50. Ortiz, S.; Thomas, E. Lower-middle Eocene benthic foraminifera from the Fortuna section (Betic Cordillera, southeastern Spain). Micropaleontology 2006, 52, 97-150. [CrossRef]

51. Boscolo Galazzo, F.; Thomas, E.; Giusberti, L. Benthic foraminiferal response to the Middle Eocene Climatic Optimum (MECO) in the South-Eastern Atlantic (ODP Site 1263). Palaeogeogr. Palaeoclimatol. Palaeoecol. 2015, 417, 432-444. [CrossRef]

52. Holbourn, A.; Henderson, A.S.; MacLeod, N. Atlas of Benthic Foraminifera, 1st ed.; Wiley-Blackwell, Natural History Museum: London, UK, 2013; p. 656.

53. Arreguín-Rodríguez, G.J.; Thomas, E.; D’haenens, S.; Speijer, R.P.; Alegret, L. Early Eocene deep-sea benthic foraminiferal faunas: Recovery from the Paleocene Eocene Thermal Maximum extinction in a greenhouse world. PLoS ONE 2018, 13, e0193167.

54. Corliss, B.H. Microhabitats of benthic foraminifera within deep-sea sediments. Nature 1985, 314, 435-438. [CrossRef]

55. Jones, R.W.; Charnock, M.A. 'Morphogroups' of agglutinating foraminifera, their life positions and feeding habits and potential applicability in paleoecological studies. Rev. Paleobiol. 1985, 4, 311-320.

56. Corliss, B.H.; Chen, C. Morphotype patterns of Norwegian Sea deep-sea benthic foraminifera and ecological implications. Geology 1988, 16, 716-719. [CrossRef]

57. Alegret, L.; Molina, E.; Thomas, E. Benthic foraminiferal turnover across the Cretaceous/Paleogene boundary at Agost (southeastern Spain): Paleoenvironmental inferences. Mar. Micropaleontol. 2003, 48, 251-279. [CrossRef]

58. Kaminski, M.A.; Gradstein, F.M. Atlas of Paleogene Cosmopolitan Deep-Water Agglutinated Foraminifera, 1st ed.; Grzybowski Foundation Special Publication: Krakov, Poland, 2005; Volume 10, p. 547.

59. Arreguín-Rodríguez, G.J.; Alegret, L.; Thomas, E. Late Paleocene-middle Eocene benthic foraminifera on a Pacific seamount (Allison Guyot, ODP Site 865): Greenhouse climate and superimposed hyperthermal events. Paleoceanography 2016, 31, 346-364. [CrossRef]

60. Hancock, H.J.L.; Dickens, G.R. Carbonate dissolution episodes in Paleocene and Eocene sediment, Shatsky Rise, west-central Pacific. In Proceedings of the Ocean Drilling Program, Scientific Results; Bralower; Bralower, T.J., Silva, I.P., Malone, M.J., Eds.; Texas A\&M University: College Station, TX, USA, 2005; Volume 198, pp. 1-24. Available online: http://www-odp.tamu.edu/ publications/198_SR/116/116.htm (accessed on 26 November 2021).

61. Pearson, P.N.; Olsson, R.K.; Hemblen, C.; Huber, B.T.; Berggren, W.A. Atlas of Eocene Planktonic Foraminifera, 1st ed.; Cushman Found. Special Publication for Foraminiferal Res.: Greenville, NC, USA, 2006; Volume 41, p. 513.

62. Pearson, P.N.; Shackleton, N.J.; Hall, M.A. Stable isotope paleoecology of middle Eocene planktonic foraminifera and multispecies isotope stratigraphy, DSDP Site 523, South Atlantic. J. Foraminifer. Res. 1993, 23, 123-140. [CrossRef]

63. Bown, P.R.; Young, J.R. Techniques. In Calcareous Nannofossil Biostratigraphy, 1st ed.; Bown, P.R., Ed.; Chapman \& Hall: London, UK, 1998; pp. 16-28.

64. Grimm, E.C. CONISS: A FORTRAN 77 program for stratigraphically constrained cluster analysis by the method of incremental sum of squares. Comput. Geosci. 1987, 13, 13-35. [CrossRef]

65. Francescangeli, F.; Armynot du Chatelet, E.; Billon, G.; Trentesaux, A.; Bouchet, V.M.P. Palaeo-ecological quality status based on foraminifera of Boulogne-sur-Mer harbour (Pas-de-Calais, Northeastern France) over the last 200 years. Mar. Environ. Res. 2016, 117, 32-43. [CrossRef] [PubMed]

66. Francescangeli, F.; Portela, M.; Armynot du Chatelet, E.; Billon, G.; Andersen, T.J.; Bouchet, V.M.P.; Trentesaux, A. Infilling of the Canche Estuary (eastern English Channel, France): Insight from benthic foraminifera and historical pictures. Mar. Micropaleontol. 2018, 142, 1-12. [CrossRef]

67. Hill, M.O.; Gauch, H.G. Detrended correspondence analysis: An improved ordination technique. Vegetatio 1980, 42, 47-58. [CrossRef]

68. Versteegh, G.J.M.; Zonneveld, K.A.F. Determination of (palaeo-) ecological preferences of dinoflagellates by applying Detrended and Canonical Correspondence analysis to Late Pliocene dinoflagellate cyst assemblages of the south Italian Singa section. Rev. Palaeobot. Palynol. 1994, 84, 181-199. [CrossRef]

69. R Core Team. R: A Language and Environment for Statistical Computing; R Foundation for Statistical Computing: Vienna, Austria, 2016; Available online: http:/ / www.r-project.org/ (accessed on 26 November 2021).

70. Juggins, S. Rioja: Analysis of Quaternary Science Data. R Package Version 0.9-26. 2020. Available online: https:// cran.r-project. org / package=rioja (accessed on 26 November 2021). 
71. Oksanen, J.; Blanchet, F.G.; Kindt, R.; Legendre, P.; Minchin, P.R.; O’Hara, R.B.; Simpson, G.L.; Solymos, P.; Stevens, M.H.H.; Wagner, H. Vegan: Community Ecology Package. R Package Version 2.3-3. 2016. Available online: https://CRAN.R-project.org/ package $=$ vegan (accessed on 26 November 2021).

72. Hammer, Ø.; Harper, D.A.T.; Ryan, P.D. Past: Paleontological statistics software package for education and data analysis. Palaeontol. Electron. 2001, 4, 9.

73. Jorissen, F.J.; Fontanier, C.; Thomas, E. Paleoceanographical proxies based on deep-sea benthic foraminiferal assemblage characteristics. In Developments in Marine Geology: Proxies in Late Cenozoic Paleoceanography, 1st ed.; Hillaire-Marcel, C., de Vernal, A., Eds.; Elsevier: Amsterdam, The Netherlands, 2007; Volume 1, pp. 264-325.

74. Boscolo Galazzo, F.; Thomas, E.; Pagani, M.; Warren, C.; Luciani, V.; Giusberti, L. The middle Eocene climatic optimum (MECO): A multiproxy record of paleoceanographic changes in the southeast Atlantic (ODP Site 1263, Walvis Ridge). Paleoceanography 2014, 29, 1143-1161. [CrossRef]

75. Moebius, I.; Friedrich, O.; Edgar, K.M.; Sexton, P.F. Episodes of intensified biological productivity in the subtropical Atlantic Ocean during the termination of the Middle Eocene Climatic Optimum (MECO). Paleoceanography 2015, 30, 1041-1058. [CrossRef]

76. Rivero-Cuesta, L.; Westerhold, T.; Agnini, C.; Dallanave, E.; Wilkens, R.H.; Alegret, L. Paleoenvironmental Changes at ODP Site 702 (South Atlantic): Anatomy of the Middle Eocene Climatic Optimum. Paleoceanogr. Paleoclimatol. 2019, 34, $2047-2066$. [CrossRef]

77. Jorissen, F.J.; De Stigter, H.C.; Widmark, J.G.V. A conceptual model explaining benthic foraminiferal microhabitats. Mar. Micropaleontol. 1995, 26, 3-15. [CrossRef]

78. Jorissen, F.J. Benthic foraminiferal successions across late Quaternary Mediterranean sapropels. Mar. Geol. 1999, 153, 91-101. [CrossRef]

79. Agnini, C.; Backman, J.; Boscolo-Galazzo, F.; Condon, D.J.; Fornaciari, E.; Galeotti, S.; Giusberti, L.; Grandesso, P.; Lanci, L.; Luciani, V; et al. Proposal for the global boundary stratotype section and point (GSSP) for the Priabonian stage (Eocene) at the Alano section (Italy). Episodes 2021, 44, 151-173. [CrossRef]

80. Birch, H.S.; Coxall, H.K.; Pearson, P.N. Evolutionary ecology of early Paleocene planktonic foraminifera: Size, depth habitat and symbiosis. Paleobiology 2012, 38, 374-390. [CrossRef]

81. Bornemann, A.; Norris, R.D. Size-related stable isotope changes in Late Cretaceous planktic foraminifera: Implications for paleoecology and photosymbiosis. Mar. Micropaleontol. 2007, 65, 32-42. [CrossRef]

82. D'Hondt, S.; Zachos, J.C.; Schultz, G. Stable isotopic signals and photosymbiosis in late Paleocene planktic foraminifera. Paleobiology 1994, 20, 391-406. [CrossRef]

83. Elderfield, H.; Vautravers, M.; Cooper, M. The relationship between $\mathrm{Mg} / \mathrm{Ca}, \mathrm{Sr} / \mathrm{Ca}, \delta^{18} \mathrm{O}$, and $\delta^{13} \mathrm{C}$ of species of planktonic foraminifera. Geochem. Geophys. Geosyst. 2002, 3, 1-13. [CrossRef]

84. Norris, R.D. Symbiosis as an evolutionary innovation in the radiation of Paleocene planktic foraminifera. Paleobiology 1996, 22, 461-480. [CrossRef]

85. Quillévéré, F.; Norris, R.D.; Moussa, I.; Berggren, W.A. Role of photosymbiosis and biogeography in the diversification of early Paleogene acarininids (planktonic foraminifera). Paleobiology 2001, 27, 311-326. [CrossRef]

86. Takagi, H.; Moriya, K.; Ishimura, T.; Suzuki, A.; Kawahata, H.; Hirano, H. Exploring photosymbiotic ecology of planktic foraminifers from chamber-by-chamber isotopic history of individual foraminifers. Paleobiology 2015, 41, 108-121. [CrossRef]

87. Wade, B.S.; Al-Sabouni, N.; Hemleben, C.; Kroon, D. Symbiont bleaching in fossil planktonic foraminifera. Evol. Ecol. 2008, 22, 253-265. [CrossRef]

88. Wendler, I.; Huber, B.T.; MacLeod, K.G.; Wendler, J.E. Stable oxygen and carbon isotope systematics of exquisitely preserved Turonian foraminifera from Tanzania-Understanding isotopic signatures in fossils. Mar. Micropaleontol. 2013, 102, 1-33. [CrossRef]

89. Spero, H.J.; DeNiro, M.J. The influence of photosynthesis on the $\delta^{18} \mathrm{O}$ and $\delta^{13} \mathrm{C}$ values of planktonic foraminiferal shell calcite. Symbiosis 1987, 4, 213-228.

90. Bé, A.W.H.; Spero, H.J.; Anderson, O.R. Effect of symbiont elimination and reinfection on the life processes of the planktonic foraminifera Globigerinoides Sacculifer. Mar. Biol. 1982, 70, 73-86. [CrossRef]

91. Wade, B.S.; Olsson, R.K. Investigation of pre-extinction dwarfing in Cenozoic planktonic foraminifera. Palaeogeogr. Palaeoclimatol. Palaeoecol. 2009, 284, 39-46. [CrossRef]

92. Pearson, P.N.; Ditchfield, P.W.; Singano, J.; Harcourt-Brown, K.G.; Nicholas, C.J.; Olsson, R.K.; Shackleton, N.J.; Hall, M.A. Warm tropical sea surface temperatures in the Late Cretaceous and Eocene epochs. Nature 2001, 413, 481-487. [CrossRef]

93. Luciani, V.; D'Onofrio, R.; Dickens, G.R.; Wade, B.S. Did Photosymbiont Bleaching Lead to the Demise of Planktic Foraminifer Morozovella at the Early Eocene Climatic Optimum? Paleoceanography 2017, 32, 1115-1136. [CrossRef]

94. Luciani, V.; D'Onofrio, R.; Filippi, G.; Moretti, S. Which was the habitat of early Eocene planktic foraminifer Chiloguembelina? Stable isotope paleobiology from the Atlantic Ocean and implication for paleoceanographic reconstructions. Glob. Planet. Chang. 2020, 191, 103216. [CrossRef]

95. Boersma, A.; Premoli Silva, I.; Shackleton, N. Atlantic Eocene planktonic foraminiferal biogeography and stable isotopic paleoceanography. Paleoceanography 1987, 2, 287-331. [CrossRef]

96. Shackleton, N.J.; Corfield, R.M.; Hall, M.A. Stable isotope data and the ontogeny of Paleocene planktonic foraminifera. J. Foraminifer. Res. 1985, 15, 321-336. [CrossRef] 
97. Wade, B.S.; Kroon, D. Middle Eocene regional climate instability: Evidence from the western North Atlantic. Geology 2002, 30, 1011-1014. [CrossRef]

98. Wade, B.S. Planktonic foraminiferal biostratigraphy and mechanisms in the extinction of Morozovella in the late middle Eocene. Mar. Micropaleontol. 2004, 51, 23-38. [CrossRef]

99. Sexton, P.F.; Wilson, P.A.; Pearson, P.N. Microstructural and geochemical perspectives on planktic foraminiferal preservation: 'Glassy' versus 'frosty'. Geochem. Geophys. Geosyst. 2006, 7, Q12P19. [CrossRef]

100. Premoli Silva, I.; Petrizzo, M.R.; Melloni, D. Data report: Planktonic foraminiferal biostratigraphy across the Cretaceous/Paleocene boundary at Shatsky Rise (ODP Leg 198, northwest Pacific). In Proceedings of the Ocean Drilling Program: Scientific Results; Bralower, T.J., Premoli Silva, I., Malone, M.J., Eds.; Ocean Drilling Program: College Station, TX, USA, 2005; Volume 198, pp. 1-16. [CrossRef]

101. Burgess, C.E.; Pearson, P.N.; Lear, C.H.; Morgans, H.E.G.; Handley, L.; Pancost, R.D.; Schouten, S. Middle Eocene climate cyclicity in the southern Pacific: Implications for global ice volume. Geology 2008, 36, 651-654. [CrossRef]

102. Pearson, P.N.; Palmer, M.R. Atmospheric carbon dioxide concentrations over the past 60 million years. Nature 2000, 406, 695-699. [CrossRef] [PubMed]

103. Coxall, H.K.; Wilson, P.A.; Pearson, P.N.; Sexton, P.F. Iterative evolution of digitate planktonic foraminifera. Paleobiology 2007, 33, 495-516. [CrossRef]

104. Resig, J.M.; Kroopnick, P.M. Isotopic and distributional evidence of a planktonic habit for the foraminiferal genus Streptochilus Brönnimann and Resig, 1971. Mar. Micropaleontol. 1983, 8, 235-248. [CrossRef]

105. Boersma, A.; Premoli Silva, I. Atlantic paleogene biserial heterohelicid foraminifera and oxygen minima. Paleoceanography 1989, 4, 271-286. [CrossRef]

106. Hallock, P.; Premoli Silva, I.; Boersma, A. Similarities between planktonic and larger foraminiferal evolutionary trends through Paleogene paleoceanographic changes. Palaeogeogr. Palaeoclimatol. Palaeoecol. 1991, 83, 43-64. [CrossRef]

107. Luciani, V.; Giusberti, L.; Agnini, C.; Backman, J.; Fornaciari, E.; Rio, D. The Paleocene-Eocene Thermal Maximum as recorded by Tethyan planktonic foraminifera in the Forada section (northern Italy). Mar. Micropaleontol. 2007, 64, 189-214. [CrossRef]

108. Wei, W.; Wise, S.W., Jr. Biogeographic gradients of middle Eocene-Oligocene calcareous nannoplankton in the South Atlantic Ocean. Palaeogeogr. Palaeoclimatol. Palaeoecol. 1990, 79, 29-61. [CrossRef]

109. Persico, D.; Villa, G. Eocene-Oligocene calcareous nannofossils from Maud Rise and Kerguelen Plateau/Antarctica): Paleoecological and paleoceanographic implications. Mar. Micropaleontol. 2004, 52, 153-179. [CrossRef]

110. Villa, G.; Fioroni, C.; Pea, L.; Bohaty, S.M.; Persico, D. Middle Eocene-late Oligocene climate variability: Calcareous nannofossil response at Kerguelen Plateau, Site 748. Mar. Micropaleontol. 2008, 69, 173-192. [CrossRef]

111. Tori, F. Variabilità Climatica e Ciclicità Nell'intervallo Eocene Oligocene: Dati dai Nannofossili Calcarei. Ph.D. Thesis, Department of Earth Sciences, University of Florence, Florence, Italy, 2008; p. 222.

112. Bukry, D. Cenozoic coccolith and silicoflagellate stratigraphy, offshore northwest Africa, DSDP Leg 41. In Deep Sea Drilling Project Initial Reports; Lancelot, Y., Seibold, E., Dean, W.E., Jansa, L.F., Eremeev, V., Gardner, J., Cepek, P., Krasheninnikov, V.A., Pflaumann, U., Johnson, D., et al., Eds.; Deep Sea Drilling Project; U.S. Govt. Printing Office: Washington, DC, USA, 1997; Volume 41, pp. 689-719.

113. Aubry, M.-P. Late Paleogene calcareous nannoplankton evolution: A tale of climatic deterioration. In Eocene-Oligocene Climatic and Biotic Evolution; Prothero, D.R., Berggren, W.A., Eds.; Princeton University Press: Princeton, NJ, USA, 1992 ; pp. $272-309$. [CrossRef]

114. Aubry, M.-P. Early Paleogene calcareous nannoplankton evolution: A tale of climatic amelioration. In Late Paleocene-Early Eocene Biotic and Climatic Events in the Marine and Terrestrial Records; Aubry, M.-P., Lucas, S.G., Berggren, W.A., Eds.; Columbia University Press: New York, NY, USA, 1998; pp. 158-201.

115. Bralower, T.J. Evidence of surface water oligotrophy during the Paleocene-Eocene thermal maximum: Nannofossil assemblage data from Ocean Drilling Program Site 690, Maud Rise, Weddell Sea. Paleoceanography 2002, 17, 13-1-13-12. [CrossRef]

116. Gibbs, S.J.; Bralower, T.J.; Bown, P.R.; Zachos, J.C.; Bybell, L.M. Shelf and open ocean calcareous phytoplankton assemblages across the Paleocene-Eocene thermal Maximum: Implications for global productivity gradients. Geology 2006, 34, 233-236. [CrossRef]

117. Agnini, C.; Fornaciari, E.; Rio, D.; Tateo, F.; Backman, J.; Giusberti, L. Responses of calcareous nannofossil assemblages, mineralogy and geochemistry to the environmental perturbations across the Paleocene/Eocene boundary in the Venetian Pre-Alps. Mar. Micropaleontol. 2007, 63, 19-38. [CrossRef]

118. Schneider, L.J.; Bralower, T.J.; Kump, L.R. Response of nannoplankton to early Eocene ocean destratification. Palaeogeogr. Palaeoclimatol. Palaeoecol. 2011, 310, 152-162. [CrossRef]

119. Kalb, A.L.; Bralower, T.J. Nannoplankton origination events and environmental changes in the late Paleocene and early Eocene. Mar. Micropaleontol. 2012, 92-93, 1-15. [CrossRef]

120. Kleijne, A. Holooccoliphorids from the Indian Ocean, Red Sea, Mediterranean and North Atlantic Ocean. Mar. Micropaleontol. 1991, 17, 1-76. [CrossRef]

121. Gibbs, S.; Shackleton, N.; Young, J. Orbitally forced climate signals in mid-Pliocene nannofossil assemblages. Mar. Micropaleontol. 2004, 51, 39-56. [CrossRef] 
122. Bukry, D. Low-latitude coccolith biostratigraphic zonation. In Proceedings of the Ocean Drilling Program, Initial Reports; Edgar, N.T., Saunders, J.B., Eds.; Ocean Drilling Program: College Station, TX, USA, 1973; Volume 15, pp. 685-703. [CrossRef]

123. Angori, E.; Bernaola, G.; Monechi, S. Calcareous nannofossil assemblages and their response to the Paleocene-Eocene Thermal Maximum event at different latitudes: ODP Site 690 and Tethyan sections. In Large Ecosystem Perturbations: Causes and Consequences; Monechi, S., Coccioni, R., Rampino, M., Eds.; Special Paper of the Geological Society of America: Boulder, CO, USA, 2007; Volume 424, pp. 69-85. [CrossRef]

124. Arrhenius, S. On the reaction rate of the inversion of non-refined sugar upon souring. Phys. Chem. 1889, 4, $226-248$.

125. Brown, J.H.; Gillooly, J.F.; Allen, A.P.; Savage, V.M.; West, G.B. Toward a metabolic theory of ecology. Ecology $2004,1771-1789$. [CrossRef]

126. Olivarez Lyle, A.; Lyle, M.W. Missing organic carbon in Eocene marine sediments: Is metabolism the biological feedback that maintains end-member climates? Paleoceanography 2006, 21, PA2007. [CrossRef]

127. John, E.H.; Pearson, P.N.; Coxall, H.K.; Birch, H.; Wade, B.S.; Foster, G.L. Warm ocean processes and carbon cycling in the Eocene. Philos. Trans. R. Soc. A Math. Phys. Eng. Sci. 2013, 371, 20130099. [CrossRef] [PubMed]

128. Ma, Z.; Gray, E.; Thomas, E.; Brandon, M.; Zachos, J.; Paytan, A. Carbon sequestration during the Palaeocene-Eocene Thermal Maximum by an efficient biological pump. Nat. Geosci. 2014, 7, 382-388. [CrossRef]

129. Wei, W.; Wise, S.W., Jr. Paleogene calcareous nannofossil magnetobiostratigraphy: Results from South Atlantic DSDP 516. Mar. Micropaleontol. 1989, 14, 119-152. [CrossRef]

130. Petrizzo, M.R.; Leoni, G.; Speijer, R.P.; De Bernardi, B.; Felletti, F. Dissolution susceptibility of some Paleogene planktonic foraminifera from ODP Site 1209 (Shatsky Rise, Pacific Ocean). J. Foraminifer. Res. 2008, 38, 357-371. [CrossRef]

131. Blaj, T.; Backman, J.; Raffi, I. Late Eocene to Oligocene preservation history and biochronology of calcareous nannofossils from paleo-equatorial Pacific Ocean sediments. Riv. Ital. Paleontol. Stratigr. 2009, 115, 67-84.

132. Hallock, P. Fluctuations in the trophic resource continuum: A factor in global diversity cycles? Paleoceanography 1987, $2,457-471$. [CrossRef]

133. Çemen, I.; Göncüolu, M.C.; Dirik, K. Structural Evolution of the Tuz Gölü Basin in Central Anatolia, Turkey. J. Geol. 1999, 107, 693-706. [CrossRef] 